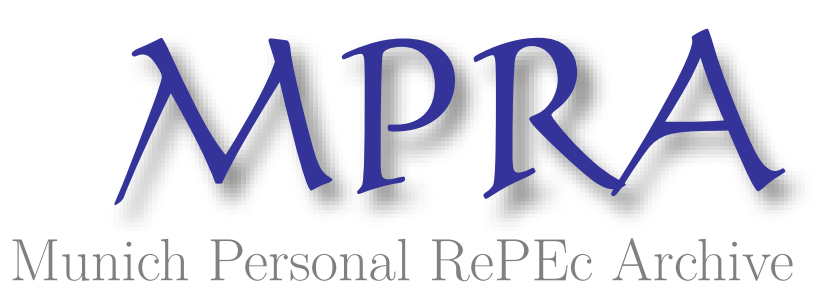

\title{
Bank credit, trade credit or no credit: Evidence from the Surveys of Small Business Finances
}

\author{
Cole, Rebel \\ DePaul University
}

15 March 2010

Online at https://mpra.ub.uni-muenchen.de/24689/

MPRA Paper No. 24689, posted 30 Aug 2010 08:28 UTC 


\title{
Bank Credit, Trade Credit or No Credit: Evidence from the Surveys of Small Business Finances
}

\author{
Rebel A. Cole \\ DePaul University \\ Chicago, IL 60404 \\ rcole@depaul.edu
}

\begin{abstract}
:
In this study, we use data from the SSBFs to provide new information about the use of credit by small businesses in the U.S. More specifically, we first analyze firms that do and do not use credit; and then analyze why some firms use trade credit while others use bank credit. We find that one in five small firms uses no credit, one in five uses trade credit only, one in five uses bank credit only, and two in five use both bank credit and trade credit. These results are consistent across the three SSBFs we examine-1993, 1998 and 2003.

When compared to firms that use credit, we find that firms using no credit are significantly smaller, more profitable, more liquid and of better credit quality; but hold fewer tangible assets. We also find that firms using no credit are more likely to be found in the services industries and in the wholesale and retail-trade industries. In general, these findings are consistent with the pecking-order theory of firm capital structure.

Firms that use trade credit are larger, more liquid, of worse credit quality, and less likely to be a firm that primarily provides services. Among firms that use trade credit, the amount used as a percentage of assets is positively related to liquidity and negatively related to credit quality and is lower at firms that primarily provide services. In general, these results are consistent with the financing-advantage theory of trade credit.

Firms that use bank credit are larger, less profitable, less liquid and more opaque as measured by firm age, i.e., younger. Among firms that use bank credit, the amount used as a percentage of assets is positively related to firm liquidity and to firm opacity as measured by firm age. Again, these results are generally consistent with the pecking-order theory of capital structure, but with some notable exceptions.

We contribute to the literature on the availability of credit in at least two important ways. First, we provide the first rigorous analysis of the differences between small U.S. firms that do and do not use credit. Second, for those small U.S. firms that do participate in the credit markets, we provide new evidence regarding factors that determine their use of trade credit and of bank credit, and whether these two types of credit are substitutes (Meltzer, 1960) or complements (Burkart and Ellingsen, 2004). Our evidence strongly suggests that they are complements.
\end{abstract}

Key words: availability of credit, bank credit, capital structure, entrepreneurship, relationships, small business, SSBF, trade credit

JEL classifications: G21, G32, J71, L11, M13

DRAFT: MARCH $15^{\text {th }}, 2010$ 


\section{Bank Credit, Trade Credit or No Credit: Evidence from the Surveys of Small Business Finances}

\section{Introduction}

Among small businesses, who uses credit? Among those that use credit, from where do they obtain funding - from their suppliers, i.e., trade credit, from their financial institutions, i.e., bank credit, or from both? The answers to these questions are of great importance not only to the small firms themselves, but also to prospective lenders to these firms and to policymakers interested in the financial health of these firms. ${ }^{1}$

The availability of credit is one of the most fundamental issues facing a small business and therefore, has received much attention in the academic literature (See, for example, Petersen and Rajan, 1994, 1997; Berger and Udell, 1995, 2006; Cole, 1998; Cole, Goldberg and White, 2004; and Cole 2008, 2009). However, many small firms - as many as one in four, according to data from the 2003 Survey of Small Business Finances - indicate that they do not use any credit whatsoever. We refer to these firms as "non-borrowers." These firms have received virtually no attention from academic researchers.

Both theory dating back to Schumpeter $(1934)^{2}$ and more recent empirical research (e.g., King and Levine, 1993a, 1993b; Rajan and Zingales, 1998) indicate that firms using little or no debt will be capital-constrained and, as a consequence, will grow more slowly, hire fewer workers and make fewer productive investments than firms utilizing debt in their capital structure. A better understanding of these firms should provide policymakers with guidance in how to tailor economic and tax policies to help small businesses obtain credit when they need

\footnotetext{
${ }^{1}$ Data from the Federal Reserve Board's Surveys of Small Business Finances indicate that about one third of all small-business debt is in the form of trade credit, about the same portion as is obtained from commercial banks. See, e.g., Robb (2002).

${ }^{2}$ Aghion and Howitt (1988) provide a comprehensive exposition of Schumpeter's theory of economic growth.
} 
credit, thereby increasing both employment and GDP.

In this study, we first analyze firms that do and do not use credit, i.e., leveraged and unleveraged firms; and then analyze how firms that do use credit (leveraged firms) allocate their liabilities between bank credit (obtained from financial institutions) and trade credit (obtained from suppliers), in order to shed new light upon these critically important issues. We utilize data from the Federal Reserve Board's 1993, 1998 and 2003 Surveys of Small Business Finances (hereafter "SSBFs") — a series of nationally representative samples of small U.S. businesses - to estimate a Heckman selection model, where the manager of a firm first decides if it needs credit, and then decides from where to obtain this credit—-from financial institutions (in the form of bank credit) or from suppliers (in the form of trade credit).

We find that one in five small firms uses no credit, one in five uses trade credit only, one in five uses bank credit only, and two in five use both bank credit and trade credit. From these results it is clear that trade credit is more than just a substitute for bank credit, as 40 percent of small businesses use both types of credit simultaneously. These results are consistent across the three SSBFs we examine-1993, 1998 and 2003.

When compared to firms that use credit, we find that non-borrowers are significantly smaller, more profitable, more liquid and of better credit quality; but hold fewer tangible assets. We also find that non-borrowers are more likely to be found in the services industries and in the wholesale and retail-trade industries. In general, these findings are consistent with the pecking-order theory of firm capital structure.

Firms that use trade credit are larger, more liquid, of worse credit quality, and less likely to be a firm that primarily provides services. Among firms that use trade credit, the amount of trade credit used (as a percentage of assets) is positively related to liquidity and negatively 
related to credit quality and is lower at firms that primarily provide services. In general, these results are consistent with the financing-advantage theory of trade credit.

Firms that use bank credit are larger, less profitable, less liquid and younger. Among these firms, the amount of bank credit used (as a percentage of assets) is positively related to firm liquidity and to firm opacity as measured by firm age. Again, these results are generally consistent with the pecking-order theory of capital structure, but with some notable exceptions. The amount of bank credit used is positively related to profitability and negatively related to tangibility of assets, both in contradiction to the pecking-order theory.

Why is this analysis of importance? According to the U.S. Department of Treasury and Internal Revenue Service, there were more than 23 million nonfarm sole proprietorships, more than 2 million partnerships with less than $\$ 1$ million in assets and more than 5 million corporations with less than $\$ 1$ million in assets that filed tax returns for $2006 .{ }^{3}$ Small firms are vital to the U.S. economy. According to the U.S. Small Business Administration, small businesses account for half of all U.S. private-sector employment and produced $64 \%$ of net job growth in the U.S. between 1993 and $2008 .{ }^{4}$ Therefore, a better understanding of who uses credit and from where they obtain financing can help policymakers to take actions that will lead to more jobs and faster economic growth.

We contribute to the literature on the availability of credit in at least two important ways.

3 See the U.S. Internal Revenue Service statistics for nonfarm sole proprietorships at http://www.irs.gov/taxstats/indtaxstats/article/0,id=134481,00.html, for partnerships at http://www.irs.gov/taxstats/bustaxstats/article/0,id=97153,00.html, and for corporations at http://www.irs.gov/taxstats/bustaxstats/article/0,id=97145,00.html. The year 2006 is used for reference because it was the latest year for which statistics were available at the time this article was written.

${ }^{4}$ See, "Frequently Asked Questions," Office of Advocacy, U.S. Small Business Administration (2009). For research purposes, the SBA and Federal Reserve Board define small businesses as independent firms with fewer than 500 employees. We follow that definition in this research. 
First, we document that one in five small U.S. firms uses no bank credit or trade credit, and provide the first rigorous analysis of the differences in these firms and other small U.S. firms that do use credit. ${ }^{5}$ A better understanding of why one in five small U.S. firms uses no credit should provide both academics and policymakers with new insights into why these firms choose not to participate in the credit markets, and what the economic and financial consequences are for such firms. Our new evidence also should provide guidance to policymakers regarding how to tailor economic and tax policies as well as regulations to encourage unleveraged firms that are credit constrained to enter the credit markets.

Second, for those small U.S. firms that do participate in the credit markets, we provide new evidence regarding factors that determine their use of and trade credit and of bank credit, and whether these two types of credit are substitutes (Meltzer, 1960) or complements (Burkart and Ellingsen, 2004). Our evidence strongly suggests that they are complements, as two in five small U.S. firms consistently use credit of both types. This is not surprising because trade credit is primarily short-term whereas bank credit is typically longer-term.

This new evidence contributes to the literature on trade credit, especially to the body of evidence regarding the validity of the financing-advantage theory of trade credit (Petersen and Rajan, 1997). This evidence has important implications for the Federal Reserve as it conducts monetary policy because trade credit can confound changes in monetary policy, depending upon whether firms increase or decrease their reliance upon trade credit when money is tight (Meltzer 1960).

\footnotetext{
${ }^{5}$ Other researchers (e.g., Chakravarty and Yilmazer (2009) and Cole (2009)) have examined differences in firms that do and do not apply for credit, but not differences in firms that do or do not use credit. According to Cole (2009), a substantial portion of firms that do not apply for credit reports substantial debt in their capital structure.
} 


\section{Review of the Literature}

\subsection{Availability of Credit to Small Businesses}

The issue of availability of credit to small businesses has been studied by financial economists for at least sixty years, dating back at least to Wendt (1947), who examines the availability of loans to small businesses in California. Since then, scores of articles have addressed this issue. We will limit our review of the literature to the most prominent studies using SSBF data that have appeared in the financial economics literature during the past two decades.

A large body of research has developed around the seminal work of Petersen and Rajan (1994), who were the first to analyze credit availability using data from the SSBF. This research has focused on the importance of firm-lender relationships in the allocation of credit. Because of the relative opacity of small firms, those firms with stronger relationships with their prospective lenders are more likely to receive credit. Petersen and Rajan (1994) use data from the 1987 SSBF to find that close ties with creditors lead to greater availability of credit at lower rates of interest.

Berger and Udell (1995) were the first to extend Petersen and Rajan, also using data from the 1987 SSBF. These authors focus their analysis only on lines of credit, a type of lending where relationships should be especially important. They find that loan rates are lower when firms have longer pre-existing relationships.

Cole (1998) was the first published study to analyze data from the 1993 SSBF. He focuses on the lender's decision whether or not to extend credit rather than on the rate charged by the lender, and finds that it is the existence, rather than the length, of the firm-lender relationship that affects the likelihood a lender will extend credit. 
Two other recent articles using the SSBF data to analyze credit to small businesses are especially relevant to the proposed study. Cole (2008) analyzes the determinants of capital structure at small U.S. businesses, testing the two major competing theories of capital structure (the pecking-order and static trade-off theories). His results are broadly supportive of the pecking-order theory, in that leverage is negatively related to firm size, age, profitability and credit quality and positively related to tangibility and limited liability. However, he provides no evidence on the subset of small businesses that choose not to use credit.

Cole (2009) analyzes firms that choose whether or not to apply for credit based upon their most recent loan application during the previous three years, and then whether or not the firms were successful in obtaining credit. He finds that firms that choose not to apply for credit are very similar to firms that do apply for and do obtain credit, and that both groups are very different from firms that apply for and are denied credit. While this study appears to be very similar to the proposed study, in fact, it is not. Cole (2009) also finds that the average firm that chose not to apply for credit reported allocating 62 percent of its assets to debt rather than equity. In other words, these firms use credit and appear to have reached their target capital structure, which explains why they did not apply for additional debt. In our proposed study, we will analyze the subset of firms that choose zero as their ratio of debt to assets.

\subsection{Use of Trade Credit by Small Businesses}

Trade credit also is an important source of funding for small businesses. In general, trade credit is considered an expensive alternative to bank debt, so researchers have sought to explain 
why it remains a pervasive source of financing for small businesses. ${ }^{6}$ In their seminal article on trade credit, Petersen and Rajan (1997) list and summarize three broad groupings of theories of trade credit: financing advantage, price discrimination and transaction costs.

According to the transactions-cost theory, which dates back to Ferris (1981), trade credit reduces the costs of paying a supplier for multiple deliveries by cumulating the financial obligations from these deliveries into a single monthly or quarterly payment. By separating the payment from the delivery, this arrangement enables the firm to separate the uncertain delivery schedule from what can now be a more predictable payment cycle. This enables the firm to manage its inventory more efficiently.

According to the financing-advantage theory, a supplier of trade credit has an informational advantage over a bank lender in assessing and monitoring the creditworthiness of its customers, which, in turn, gives the supplier a cost advantage in lending to its customers. The supplier also has a cost advantage in repossessing and reselling assets of its customers in the event of default (Mian and Smith, 1992). Smith (1987) argues that, by delaying payment via trade credit, customers can verify the quality of the supplier's product before paying for that product. In a theoretical paper, Biais and Gollier (1997) assume that suppliers have private information about their customer and demonstrate that trade credit alleviates information asymmetries that otherwise would preclude financing of positive NPV projects. According to Burkart and Ellingsen (2004), the information advantage derives from the transaction by which the supplier provides inputs to its customer, in that cash is easily diverted but input supplies are not. In addition, this may boost investment, leading banks to increase their lending to the

\footnotetext{
${ }^{6}$ Based upon the traditional " $2 / 10$ net 30 " terms of trade credit, where the customer gets a $2 \%$ discount for paying within ten days and pays no penalties so long as payment in full is made within 30 days, the implied interest rate for a firm paying on the $30^{\text {th }}$ day is approximately $45.5 \%$ on an annual percentage rate basis. $\left(2 \%\right.$ compounded for $(365 / 20)$ periods, or $1.02^{\wedge}(365 / 20)-1$.)
} 
customer, as well. Hence, trade credit can be a complement to bank credit.

According to the price-discrimination theory, which dates back to Meltzer (1960), a supplier uses trade credit to price discriminate among its customers. Creditworthy customers will pay promptly so as to get any available discounts while risky customers will find the price of trade credit to be attractive relative to other options. The supplier also discriminates in favor of the risky firm because the supplier holds an implicit equity stake in the customer, equal to the present value of future profits from sales to the customer, and wants to protect that equity position by extending temporary short-term financing. Meltzer (1960) concludes that trade creditors redistribute traditional bank credit during periods of tight money, so that trade credit serves as a substitute for bank credit when money is tight. Nilsen (2002) provides strong empirical support for Meltzer's conclusions, as well as supporting the existence of a "bank lending channel" for the transmission of monetary policy. ${ }^{7}$

One version of the price-discrimination theory posits that trade creditors are more lenient than bank lenders when a firm encounters financial distress, so that riskier firms will allocate a larger share of their borrowing to trade creditors in exchange for the financial flexibility they obtain in the event that they become distressed. Suppliers have what amounts to an equity stake in the firms to which they lend and, therefore, are more accommodating to their customers when the customers encounter financial problems. Bank lenders, on the other hand, are more likely to be secured by collateral and hold claims that are senior to those of trade creditors, so they are more likely to pursue liquidation in the event of default than are trade creditors (Berger and Udell, 1998). Huyghebaert, Van de Gucht and Van Hulle (2007) provide empirical evidence in support of this theory, finding that Belgian firms in industries with high historical failure rates

\footnotetext{
${ }^{7}$ The bank "lending channel" theory posits that banks respond to tight monetary policy by contracting loan volume, which reduces investment by borrowing firms.
} 
and high liquidation values use more trade credit that other Belgian firms.

Petersen and Rajan (1997) use data from the 1987 SSBF to find that the information provided by banking relationships does not appear to affect the amount of trade credit offered by suppliers, which they interpret as supportive of the financing-advantage theory that suppliers collect and use different private information about their customers than do financial institutions. Petersen and Rajan also find that small U.S. firms with longer banking relationships hold lower levels of accounts payable than other firms, while firms in metropolitan areas with few financial institutions held higher levels of accounts payable than firms in other metropolitan areas. They interpret their results as evidence that trade credit falls below bank credit in the pecking order of capital structure, consistent with Meltzer (1960).

Fisman and Love (2003) extend this line of research by examining small firms in countries with less developed financial markets and find that "firms in industries with higher rates of accounts payable exhibit higher rates of growth.” Love, Preve and Sarria-Allende (2007) find that trade credit in Asian countries fell for several years following the 1997 Asian financial crisis. They interpret their evidence as consistent with a redistribution view of trade credit, whereby financially strong firms redistribute bank credit to financially weak firms.

Ng, Smith and Smith (1999) contradict Meltzer's bank-substitute theory but support Ferris' transaction-cost theory with evidence based upon a survey of credit managers at publicly traded U.S. firms listed on CompuStat. They conclude that "credit terms are stable over time" and that firms "do not respond to fluctuations in market demand" but that there is "wide variation across industries in credit terms, but little variation within industries."

Cuñat (2007) argues that trade creditors have an advantage over bank creditors in collecting non-collateralized lending, in that a trade creditor can threaten to cut off goods that it 
supplies to the borrower so long as switching suppliers is costly. This advantage enables trade creditors to lend more than banks are willing to lend. In this sense, trade credit is a complement rather than a substitute for bank credit, and firms should be expected to utilize both types of credit even when banking markets are competitive. However, this relationship also will lead trade creditors to provide liquidity to borrowers that are facing temporary liquidity problems and at increased level of financial distress. Cuñat uses panel data on U.K. firms from the FAMEBureau Van Dijk database to test his model.

\section{Data}

To conduct this study, we use data from the Federal Reserve Board's 1993, 1998 and 2003 Surveys of Small Business Finances. ${ }^{8}$ In each survey, the firms surveyed constitute a nationally representative sample of small businesses operating in the U.S. as of year-end prior to the survey, where a small business is defined as a non-financial, non-farm enterprise employing fewer than 500 employees. The 1993 (1998) survey data are broadly representative of approximately five million firms operating in the U.S. as of year-end 1993 (1998) while the 2003 survey data are broadly representative of approximately six million firms operating in the U.S. as of year-end 2003.

The SSBF provides detailed information about each firm's sources of financing as well as information about each firm's balance sheet, either of which can be used to determine whether or not a firm uses trade credit and/or bank credit. We choose to used the detailed information about financing sources rather than rely upon the balance-sheet data. Specifically, each SSBF includes

${ }^{8}$ See Elliehausen and Wolken (1990) for a detailed description of the 1987 survey, Cole and Wolken (1995) for a detailed description of the 1993 survey, Bitler, Robb and Wolken (2001) for a detailed description of the 1998 survey, and Mach and Wolken (2006) for a detailed description of the 2003 survey. 
a question asking whether or not the firm used trade credit in the reference year of the survey, and asking whether or not the firm had any outstanding bank credit in the reference year of the survey. We use the answers to these questions to classify a firm as using no credit, using trade credit only, using bank credit only, or using both bank credit and trade credit.

Specifically, we classify a firm as "using trade credit" if the firm reported that it did use trade credit in the reference year of the survey. ${ }^{9}$ We classify a firm as "using bank credit" if the firm reported that it had any loans outstanding in the reference year of the survey. ${ }^{10}$ We classify a firm as "using no credit" if the firm reported that it used no trade credit and that it used no bank credit during the reference year. Similarly, we classify a firm as "using both bank credit and trade credit" if it reported that it used both bank credit and used trade credit.

We calculate the amount of bank credit from the outstanding balances reported by the firm for each type of loan. We are forced to estimate the amount of trade credit from the amount of accounts payable because the questionnaire does not ask the firm to report this amount.

For firms obtaining credit, the SSBF provides information on the identity and characteristics of the lender through a series of questions about the firm's use of financial services, including lines of credit, mortgage loans, equipment loans, motor vehicle loans and other loans. For each type of loan, the SSBF identifies the amount of the loan and the type of

${ }^{9}$ In the 2998 and 2003 SSBFs, the firm was asked "During [YEAR], did [FIRM] make any purchases of goods or services from suppliers on account rather than pay before or at the time of the delivery?" In 1993, the question was slightly different: "Did the firm purchase any goods or services on account during 1993 rather than pay for the purchases before or at the time of delivery?

${ }^{10}$ Each SSBF includes a series of questions about the firm's use of credit during the reference year of the survey, including lines of credit, mortgages, motor vehicle loans, equipment loans, leases, owner loans and other loans. We classify a firm as using bank credit if it answered yes to any of these questions except for owner loans. For example, the firms were asked "During [YEAR], did the firm have any business lines of credit or revolving credit agreements?" If the firm answers "yes" then it also is asked for the outstanding balance of all loans of that type. We use this information to calculate the amount of bank credit. 
institution extending the credit. ${ }^{11}$

The survey data also provide information on each firm's balance sheet and income statement; its credit history; the firm's characteristics, including standard industrial classification (SIC), organizational form, and age; and demographic characteristics of each firm's primary owner, including age, education, experience, and credit history. Balance-sheet and incomestatement data are derived from the enterprise's year-end financial statements. Credit history, firm characteristics, and demographic characteristics of each firm's primary owner are taken as of year-end.

\section{Methodology}

In order to provide new evidence on who uses credit and from where, we employ both univariate and multivariate tests. In all of our tests, we employ the survey sampling weights because the SSBFs do not consist of random samples; rather, they are stratified random samples, where large and minority-owned firms are over-represented relative to smaller and white-owned firms.

First, as described above, we classify firms into one of four categories of borrower type based upon their responses to questions regarding the structure of their liabilities. Use No Credit firms are those firms that reported using no bank credit and using no trade credit; Use Credit firms are those firms that reported using either or both types of credit.

${ }^{11}$ The 2003 SSBF includes questions that ask the respondent to identify the type of institution or source for each financial service it obtains, including all loans. The categories are:

1: commercial bank; 2: savings bank; 3: savings and loan association; 4: credit union; 5: finance company; 6: insurance company; 7: brokerage or mutual fund company; 8: leasing company; 9: mortgage company; 10: venture-capital firm or small-business investment company; 11: other business firm; 12: family or other individual; 13: government agency (includes SBA); 14: other type; 15: supplier firm; 16: credit card processing; 17: check clearing; 18: factoring; 19: owner, himself or herself; 20: 401K/retirement; and 21: consolidated/multiple institutions. 
Once we have classified our sample firms, we calculate descriptive statistics for Use No Credit firms and Use Credit firms, and then test for significant differences in these two types of firms. For Use Credit firms, we also provide descriptive statistics on use of the two different sources of credit, e.g., trade credit and bank credit.

We also conduct multivariate tests on the data. First, we use a weighted univariate probit regression model to test hypotheses about differences in the Use Credit firms and Use No Credit firms.

$$
\text { borrower type }=\mathrm{f}(\text { firm characteristics, owner characteristics })
$$

where:

borrower type is equal to one if the firm is a use credit firm and equal to zero if the firm is a use no credit firm, as defined above; firm characteristics is a vector of variables related to the firm that are expected to influence availability of credit, such as credit history, size, profitability, age, leverage, etc.; and owner characteristics is a vector of variables related to the primary owner that are expected to influence availability of credit, such as age, education, race, ethnicity and gender.

These tests provide the first comprehensive and rigid statistical evidence on how these two groups of firms differ.

Third, we use equation $1 \mathrm{~A}$ as the first equation in bivariate-probit selection model (see Van de Venn and Van Pragg (1981) and Greene (1992) and (1996)), where the second equation 
is a model of whether the firm used trade credit (equation 2A) or an model of whether the firm used bank credit (equation $2 \mathrm{~B}):^{12}$

$$
\text { use trade credit }=\mathrm{f}(\text { firm characteristics, } \text { owner characteristics })
$$

where:

use trade credit is equal to one if the firm uses trade credit and equal to zero otherwise.

use bank credit $=\mathrm{f}($ firm characteristics, owner characteristics $)$

where:

use bank credit is equal to one if the firm uses bank credit and equal to zero otherwise.

This selection model is an extension of the bivariate probit model, which itself is an extension of the univariate probit model. We use a probit model because our dependent variables are binary (i.e., they take on a value of zero or one), so that ordinary least squares is inappropriate. We use a bivariate probit selection model to estimate equations (2A) and (2B) in order to account for a non-random selection mechanism operating on those firms that use trade credit and on those firms that use bank credit. We cannot use the standard Heckman (1979) selection model because the dependent variable in our second equation is binary; in Heckman's model, the dependent variable in the second equation is continuous and can be estimated by weighted least squares. The bivariate probit model consists of two equations

$$
\mathrm{y}^{*}{ }_{1}=\beta_{1}{ }^{\prime} \mathrm{x}_{1}+\epsilon_{1}, \mathrm{y}_{1}=\operatorname{sign}\left(\mathrm{y}_{1}{ }_{1}\right)
$$

and

$$
\mathrm{y}_{2}{ }_{2}=\beta_{2}{ }^{\prime} \mathrm{x}_{2}+\epsilon_{2}, \mathrm{y}_{2}=\operatorname{sign}\left(\mathrm{y}^{*}{ }_{2}\right)
$$

${ }^{12}$ See Greene (2003) for more information about the bivariate probit model. 
where:

$$
\epsilon_{1}, \epsilon_{2} \sim \operatorname{Bivariate} \operatorname{Normal}(0,0,1,1, \rho)
$$

In the bivariate probit selection model, $\left[\mathrm{y}_{1}, \mathrm{x}_{1}\right]$ are only observed when $\mathrm{y}_{2}$ is equal to one, so the error terms in equations (1) and (2) must be re-specified as $\epsilon_{j}=\exp \left(\gamma_{j}, z_{j}\right)$ uj, where $\left[u_{1}, u_{2}\right]$ have the bivariate standard normal distribution. The estimated correlation coefficient $\rho$ (the correlation between error terms $\epsilon_{1}$ and $\epsilon_{2}$ ) can be used to test for selection bias. If $\rho$ is statistically significant, then we can reject the null hypothesis that selection bias is not present.

Fourth, we use equations $2 \mathrm{~A}$ and $2 \mathrm{~B}$ as the first equation in the standard two-equation Heckman sample-selection estimator estimated by the method of maximum likelihood, where the second equation is a model of the percentage of assets allocated to trade credit (equation $3 \mathrm{~A}$ ) or the percentage of assets allocated to bank credit (equation 3B):

trade credit percentage $=\mathrm{f}($ firm characteristics, owner characteristics $)$ where:

trade credit percentage is equal to the percentage of total assets allocated to trade credit;

bank credit percentage $=\mathrm{f}($ firm characteristics, owner characteristics $)$

where:

bank credit percentage is equal to the percentage of total assets allocated to bank credit.

For explanatory variables, we generally follow the existing literature on the availability of credit and capital structure. We include a vector of firm characteristics that includes public reputation as proxied by the log of firm age; firm size as measured by the log of sales; firm credit quality as proxied by firm delinquency (whether or not the firm has been delinquent on business 
obligations during the previous three years); firm profitability as measured by return on assets; firm financial slack as proxied by the ratio of cash to total assets; firm current assets as measured by the sum of accounts receivable, inventory and other current assets scaled by total assets; firm tangible assets as measured by the sum of land and depreciable assets scaled by total assets; firm governance as measured by percentage ownership of the primary owner and a dummy variable for corporations; and firm industry as measured by a set of nine dummy variables for one- or two-digit SIC code defining nine broad industries (construction, primary manufacturing, secondary manufacturing, transportation, wholesale trade, retail trade, insurance and real estate, business services and professional services).

A vector of owner characteristics includes the race (Asian or Black), ethnicity (Hispanic) and gender (Female) as measured by dummy variables indicating that the firm's primary owner is Black, Hispanic, Asian and female, respectively; owner's reputation as measured by the log of Owner Age; owner's business experience as measured by the number of years that the primary owner has been an owner or manager of a business; dummy variables for the highest educational attainment of the firm's primary owner (High School Degree, Some College, College Degree or Graduate Degree); owner credit quality as proxied by Owner Delinquency (whether or not the primary owner has been delinquent on personal obligations). Table 1 presents a summary of the variable definitions.

\section{Hypotheses}

\subsection{Firms that Use Credit vs. Firms that Use No Credit}

Our primary hypotheses relate to differences between firms that use credit and firms that use no credit, i.e., that use no bank credit and use no trade credit. This eliminates a large number 
of potential explanatory variables, such as firm leverage and the outcome of the firm's most recent loan application, as these variables can only take on certain values when the firm uses credit. However, there remain a large number of variables of interest that we can use to test our hypotheses - many of which are tied to the pecking-order theory and trade-off theory of capital structure. $^{13}$

The pecking-order theory of capital structure suggests that profitable firms, firms with more "financial slack," and firms in certain industries that require little in the way of tangible assets use less debt than other firms. Therefore, we expect that use no credit firms have higher return on assets, have more cash (our proxy for financial slack), have fewer tangible assets and are more likely to be in the service industries (insurance/real estate, business services and professional services) than are use credit firms. Corporations enjoy limited liability and therefore should be more likely to use credit, so we expect to find a positive relation between corporation and use credit.

Behavior finance suggests that owners of use no credit firms act irrationally, as these firms are failing to take advantage of either the interest-free financing from typical trade credit terms or the debt-tax shield from bank financing, as well as the opportunity to leverage up their return on equity. ${ }^{14}$ The managers of these firms may simply be financially unsophisticated, or may have an irrational aversion to debt of any form and prefer to pay cash for all purchases. Therefore, we hypothesize that use no credit firms are more likely to be minority-owned (Asian,

${ }^{13}$ Cole (2008) explores in detail how the static trade-off and pecking-order theories of capital structure explains the capital structure of small U.S. firms.

${ }^{14}$ More than ten percent of the firms reporting zero debt in the 2003 SSBF also reported that they did not apply because they feared rejection, which is arguably irrational as the costs of applying are negligible while the gains from applying (potentially receiving a loan) are quite large. This group of discouraged firms may be quite different from firms that report zero debt and did not apply simply because they did not need credit. 
Black or Hispanic), located in rural areas, and have owners with less experience and less education than other types of firms. (We measure education using a two dummy variables for highest educational attainment—college and graduate.

\subsection{Firms that Use Trade Credit and Firms that Use Bank Credit}

Among firms reporting that they use credit, we also test hypotheses regarding the choice between trade credit and what we will generically refer to as "bank credit," which encompasses all other sources of credit (see footnote 11 for a comprehensive list) but is dominated by credit from banks and other financial institutions.

One version of the price-discrimination theory suggests that trade creditors are more lenient in the event of default than are bank creditors, who tend to hold more secure positions in liquidation largely due to collateralization. Therefore, we expect to find that variables indicating worse credit quality are associated with higher allocations of total liabilities to trade credit. These include the $D \& B$ credit score, the number of firm delinquencies, and the number of owner delinquencies.

Petersen and Rajan (1997) hypothesize that trade creditors use information developed by banks in evaluating customers for trade credit. They use two proxies for bank information to test this hypothesis. First, the authors calculate the length of the firm's longest bank relationship. Second, they use information from the firms' most recent loan application to construct a variable indicating that the firm was denied credit. We also calculate these two variables and expect negative relations with the use of trade credit.

Owners with greater private benefits of control should allocate more of their liabilities to trade credit so as to ensure that they do not lose those benefits of private control. We follow the 
corporate governance literature in measuring the benefits of private control using the "wedge" between ownership and control (see Claessens, Djankov and Lang (2000)). The larger is the primary owner's ownership percentage, the less he has to gain from self-dealing and perquisite consumption. The logic of this measure follows from the seminal paper on agency costs and ownership structure by Jensen and Meckling (1976), which is tested using small business data by Ang, Cole and Lin (2000). When the primary owner owns $100 \%$ of the firm, each dollar of perquisite consumption costs him one dollar, but as ownership falls to $\alpha$, where $0 \%<\alpha<100 \%$, the primary owner's cost fall to $\alpha$ times one dollar. In other words, the primary owner realizes the full benefit of the perquisite consumption, but the cost of the perquisite consumption is only his ownership percentage times the value of the perquisites. We hypothesize that the ownership percentage should be negatively related to the use of any credit—bank or trade.

According to the financing-advantage theory, bank creditors are more likely than trade creditors to liquidate a firm when liquidation value is greater than the value of the firm as a going concern because they have a much smaller implicit equity stake in the firm. Therefore, we hypothesize that firms with greater liquidation value will use more trade credit. We proxy the value of assets in liquidation using the ratio of tangible assets to total assets, where tangible assets are defined as the sum of land and depreciable assets. Alternatively, firms with more tangible assets may prefer to finance them with credit of matched maturity, so that they prefer to use more bank credit. If this is the case, then we expect tangible assets to have a negative relation with the use of trade credit and a positive relation to the use of bank credit.

Owners of firms with greater growth opportunities have more to lose in liquidation than other firms, as the present value of those growth opportunities is lost. Therefore, growth firms should favor equity over bank debt, but favor trade credit over bank debt because, according to 
the financing-advantage theory, trade creditors are expected to be more lenient to firms in financial distress. We proxy growth opportunities using an indicator variable for growth is positive defined as equal to one if the firm reports that its annual sales revenues had increased from the prior period and equal to zero otherwise. We expect a negative relation between growth is positive and both use credit and use bank credit but a positive relation with use trade credit.

According to Meltzer's bank-substitute theory, the use of trade credit relative to bank credit should be greater during times of tight money. By comparing statistics from the three SSBFs, we should be able to shed some light on this theory, as the target Fed Fund rate varied from $1.00 \%$ in 2003 to $3.00 \%$ in 1993 and a high of $5.50 \%$ during the first three quarters of 1998. Therefore, we expect to find the lowest percentage of assets allocated to trade credit in 2003 and the highest in 1998, with 1993 falling in between.

Petersen and Rajan (1997, p. 678) point out that the interest-free financing from typical trade credit terms ( $2 / 10$ net 30$)$ "dominates paying cash," so that one should "expect all firms to borrow during the initial period." Yet our survey data show that many firms do not borrow. We hypothesize that firms in certain industries have little or no need for trade credit, such as those in insurancelfinance, business services and professional services, while others have very large needs, such as those in construction and manufacturing. Firms in industries characterized by large investments in tangible and depreciable assets, such as construction, manufacturing, and transportation, also should be more likely to use bank credit. 


\section{Results}

\subsection{Univariate Results}

Table 2 shows the distributions of firms from each of the three SSBFs into four categories based upon whether or not the firm used trade credit or bank credit during the survey year: no credit, trade credit only, bank credit only, and bank and trade credit. Interestingly, the distributions are remarkably similar across the three surveys: roughly twenty percent of the firms fall into each of the first three categories with the remaining forty percent falling into the bank and trade credit category. In other words, one in five firms uses no credit, and roughly three out of five firms use trade credit and three out of five firms use bank credit, but roughly one in five firms uses bank credit but not trade credit and roughly one in five firms uses trade credit but not bank credit.

These distributions provide some evidence on Meltzer's bank-substitute theory. Consistent with this theory, the use of bank credit only was highest in 2003 when interest rates were lowest and lowest in 1998 when interest rates were highest, whereas use of trade credit only was highest in 1998 and lowest in 2003.

Table 3A, 3B and 3C present descriptive statistics from the 1993, 1998 and 2003 SSBFs, respectively, first for the full sample, and then separately for Use credit firms and use no credit firms. The tables also present the results from a $t$-test for statistically significant differences in the means of the use credit and use no credit firms.

For the full sample of the $2003 \mathrm{SSBF}$ (shown in Table 3A), the average firm had annual sales of $\$ 624,307$, return on assets (ROA) of 55.7 basis points, had current assets equal to 31 percent of total assets, had tangible assets equal to 33 percent of total assets, had growth in sales for 41 percent of the sample, was organized as a corporation for 45 percent of the sample, had 
been in business for 14.2 years and had a categorical $D \& B$ credit score of 3.61 (where 1 is worst and 6 is best). The average owner was 51.5 years old, and 26.3 percent of owners were female, 3.9 percent were Black and 4.4 percent were Hispanic; 29.1 percent had a college degree, 20.8 percent had a graduate degree and the rest had less than a college degree. By industry, 11.7 percent were in construction, 7.1 percent were in manufacturing, 3.9 percent were in transportation, 5.7 percent were in wholesale trade, 18.7 percent were in retail trade, 6.7 percent were in insurance/real estate (financial institutions are excluded), 25.3 percent are in business services and 21.0 percent are in professional services.

When compared with firms that use credit, firms that use no credit are significantly smaller as measured by sales $(\$ 179,933$ vs. $\$ 741,592)$, more profitable as measured by $R O A$ (73.5 basis points vs. 51.0 basis points), allocate less of their assets to both current assets (29.4 percent vs. 31.0 percent) and tangible assets (27.8 percent vs. 34.1 percent), are less likely to be growing in terms of sales ( 32.1 percent vs. 42.8 percent), are less likely to be organized as corporations (27.1 percent vs. 49.7 percent), are younger (12.97 years vs. 14.51 years) and have worse credit scores (3.459 vs. 3.650). Owners of firms that use no credit are older as measured by owner age ( 52.2 years vs. 51.3 years), more likely to be female (39.2 percent vs. 22.9 percent) or Black (6.0 percent vs. 3.4 percent); They also are better educated with a college or graduate degree (55.6 percent vs. 48.4 percent). By industry, use no credit firms are significantly more likely to be found in business services and professional services and significantly less likely to be found in construction, manufacturing, transportation and wholesale trade.

If we look across Tables 3A, 3B and 3C, we find a number of regularities with respect to differences in use credit and use no credit firms, as defined by statistically significant differences in means in each of the three SSBFs. Use credit firms are consistently larger as measured by both 
assets and sales, more profitable as measured by ROA, have less financial slack as measured by the ratio of cash to assets, are more likely to be organized as corporations, are much more likely to report firm delinquencies, are less likely to be located in rural areas. The owners of use credit firms are consistently younger, less likely to be female and have a smaller ownership percentage of the firm. By industry, Use Credit firms are more likely to be found in construction, manufacturing and wholesale trade and less likely to be found in professional services.

\subsection{Multivariate Results}

\subsection{Univariate Probit Model Explaining Differences in}

\section{Firms that Use Credit and Firms that Use No Credit}

Table 4 presents the results from estimating equation (1) using a weighted univariate probit model to explain differences in use no credit firms and use credit firms from each of the three SSBFs. Many of the significant differences vary, and often change signs across the three surveys, so we will focus on the results that are consistent across the three surveys. The multivariate results largely confirm findings from the univariate results presented in Tables $3 \mathrm{~A}$, $3 \mathrm{~B}$ and $3 \mathrm{C}$.

As compared to use no credit firms, use credit firms are significantly larger as measured by the log of annual sales, less profitable as measured by return on assets, have less financial slack as measured by cash, and are more likely to report business delinquencies. However, in a multivariate setting, use credit firms have significantly fewer tangible assets, in contrast with the univariate results. Use credit firms are more likely to be organized as corporations in 1998 and 2003 but not in 1993, in spite of the large univariate difference; in 1993, 51.5\% of use credit firms were corporations as compared with $32.6 \%$ of use no credit firms. 
Owners of use credit firms are significantly younger as measured by the log of owner age, but more experiences as measured by the number of years owning or managing a business, and own a smaller percentage of the firm. Differences by race, ethnicity, gender and educational attainment are not consistently significant.

By industry, use credit firms are significantly less likely to be classified as professionalservices and business-services firms, insurance/real estate firms,) and wholesale-trade and retailtrade firms as compared with the omitted category of construction firms.

\subsection{Bivariate Probit Selection Model Explaining Differences in \\ Firms that Use Trade Credit and Firms that Use No Trade Credit Firms}

Table 5 presents the results from estimating equation $2 \mathrm{~A}$ to explain differences in firms that use trade credit from firms that use no trade credit, conditional upon using either trade credit or bank credit. This equation is estimated using a bivariate probit selection model, where we first estimate equation 1 using the full sample and then estimate equation $2 \mathrm{~A}$ including only those firms that reported using either bank credit or trade credit. The estimated correlation between the error terms in the two equations is statistically indistinguishable from zero, indicating that sample-selection bias is not present when we estimate equation $2 \mathrm{~A}$ with a simple probit model. (Results obtained when we estimate equation $2 \mathrm{~A}$ using the full sample and no selection equation are qualitatively similar to those reported in Table 5.)

As compared to use no trade credit firms, use trade credit firms are significantly larger as measured by the log of sales, have more financial slack as measured by the ratio of cash to assets, and allocate more of their assets to current assets (primarily accounts receivable and inventory), and have worse credit quality as proxied by firm delinquency. Return on assets 
(ROA) is consistently negative but fails to come close to statistical significance. Sales growth, corporation, firm age and MSA each flips sign across surveys.

Owners of use trade credit firms are significantly less likely to be Hispanic and are consistently more educated in terms of having at least a college degree but the education variables lack significance in 1998. Percentage ownership is consistently negative but is significant only in 1993. Black is consistently negative but is significant only in 2003. Age and experience both are consistently positive, but lack statistical significance.

By industry, use trade credit firms are significantly less likely to be classified as business-services or professional-services firms, insurance/real estate firms, retail-trade firms and transportation firms as compared with the omitted category of construction firms.

\subsection{Bivariate Probit Selection Model Explaining Differences in \\ Firms that Use Bank Credit and Firms that Use No Bank Credit}

Table 6 presents the results from estimating equation 2B to explain differences in firms that use bank credit from firms that use no bank credit, conditional upon using either bank credit or trade credit. Again, this equation is estimated using a bivariate probit selection model, where we first estimate equation 1 using the full sample and then estimate equation 2B including only those firms that use either bank credit or trade credit. Again, the estimated correlation between the error terms in the two equations is statistically indistinguishable from zero, indicating that sample-selection bias is not present when we estimate equation $2 \mathrm{~B}$ with a simple probit model. (Results obtained when we estimate equation 2B using the full sample and no selection equation are qualitatively similar to those reported in Table 6.)

As compared to use no bank credit firms, use bank credit firms are significantly larger as 
measured by the log of sales, are less profitable as measured by ROA, have less financial slack as measured by the ratio of cash to assets and are more opaque (younger) as measured by the log of firm age. Sales growth is consistently positive in sign but significant only in 1993. The remaining firm variables switch signs across surveys. In general, these results are inconsistent with the "core factors" reported by Frank and Goyal (2007) as being the primary determinants of firm leverage; whereas they find a positive relation between leverage and tangible assets and a negative relation between firm leverage and profitability, we find exactly the opposite. Our findings with respect to firm size are consistent: larger firms use more leverage. In general, these results also are inconsistent with the pecking-order theory, which predicts a negative sign for firm profitability and a positive sign for tangible assets.

Owners of use bank credit firms are consistently younger as measured by log of owner age, more educated as measured by having a college or graduate degree, and less likely to be female or Asian and more likely to be Hispanic, but none of these variables is statistically significant across the three SSBFs. The remaining owner variables flip signs across the surveys.

By industry, use bank credit firms are significantly more likely to classified as transportation and insurance/real estate and less likely to be classified as wholesale-trade or retail-trade firms as compared with the omitted category of construction firms.

\subsection{WLS Regression to Explain Amount of Trade Credit Used}

Table 7 presents the results from estimating equation $3 \mathrm{~A}$ to explain the amount of trade credit used by the firm, conditional upon the firm using trade credit. This equation is estimated using a two-equation sample-selection model as developed by Heckman (1979), where we first estimate equation $2 \mathrm{~A}$ using the full sample and then estimate equation $3 \mathrm{~A}$ including only those 
firms that use trade credit. The estimated correlation between the error terms in the two equations is statistically indistinguishable from zero, indicating that sample-selection bias is not present when we estimate equation $3 \mathrm{~A}$ with a simple weighted-least-squares model.

Consistent with a number of previous studies, we find that the amount of trade credit used decreases with the log of firm age, indicating that younger, more opaque firms about which less information is available, rely more heavily upon trade credit. Cuñat (2007) uses firm age as a proxy for the strength of the relationship between the trade creditor and borrower and finds a nonlinear relation between firm age and the amount of trade credit used, first rising during the first five years of a firm's life and then declining subsequent to that period. We also test nonlinear specifications (not shown) where firm age is fit as a two-part spline function of zero to five years and then six or more years, as suggested by Cuñat's results. Our results fail to support Cuñat, in that both variables are either insignificant or negative and significant; we do not find a positive relation for younger firms.

The amount of trade credit used is positively related to financial slack as measured by the ratio of cash to assets and to current assets as measured by the sum of accounts receivable, inventory and other current assets scaled by total assets. This finding with respect to current assets supports our hypothesis that firms try to match the maturities of their assets and liabilities, so that firms with high levels of current assets will attempt to fund those assets with current liabilities in the form of accounts payable. The finding with respect to cash contrasts with those of Cuñat (2007), who finds a negative relation between the amount of trade credit used and liquid assets, and argues against his theory that firms use more trade credit when they face liquidity constraints. This discrepancy in findings may be attributable to the fact that Cuñat (2007) relies upon the FAME database, which provides little information beyond basic balance- 
sheet data; the SSBFs are much more comprehensive datasets, but at the cost of being crosssectional snapshots. For example, Cuñat (2007) has no information on the credit quality of the firm or its owner, both of which are consistently significant in our results.

The amount of trade credit used is greater both when firm credit quality is worse as proxied by firms reporting business delinquencies and when owner credit quality is worse as proxied by the primary owner reporting delinquencies on personal obligations. These results contradict those of Petersen and Rajan (1997), who find that firms with higher credit quality as measured by firm size and profitability use more trade credit. However, Petersen and Rajan rely upon the $1987 \mathrm{SSBF}$, which did not provide the superior measures of credit quality available in the three iterations of the SSBF used in this study. In addition, as Cuñat points out, firm size also is an important control for the level of the firm's activity, so it may be inappropriate to use it as a proxy for firm credit quality.

When we include the ratio of tangible assets to total assets in our model (not shown), we find that this variable is negative and statistically significant; this finding support the prediction from Cuñat's model that firms with fewer tangible asset (that can be pledged as loan collateral) should use more trade credit. This finding also is consistent with the results of Petersen and Rajan (1997), who find a negative relation between the amount of trade credit used and tangible assets.

Other than credit quality, none of the owner characteristics are consistently significant in explaining the amount of trade credit used, with most flipping signs across the three surveys.

By industry, the amount of trade credit used is consistently and significantly smaller among firms in the business services, professional services, insurance/real estate, and retailtrade industries, as compared with the omitted category of construction firms. These results 
strongly support our hypothesis that use of trade credit is strongly related to a firm's industry, with firms that primarily provide services expected to use significantly less trade credit than those that provide tangible products.

Not shown in Table 7 are additional regressions where we include the length of the firm's relationship with its primary financial institution and whether or not the firm was denied credit during its most recent loan application. Petersen and Rajan (1997) interpret these as proxies for financial institutions' information about the firm, and argue that it should be positive and significant in explaining the amount of trade credit used if trade creditors use financial institutions' information in making their decisions to grant trade credit to the firm. Our results are consistent with Petersen and Rajan; like them, we find that both of these variables are statistically insignificant in explaining the amount of trade credit used. We follow them in interpreting this as evidence that trade creditors generate and rely upon their own information set in deciding whether to grant trade credit.

\subsection{WLS Regression to Explain Amount of Bank Credit Used}

Table 8 presents the results from estimating equation 3B to explain the amount of bank credit used by the firm (scaled by total assets), conditional upon the firm using bank credit. This equation also is estimated using a two-equation sample-selection model as developed by Heckman (1979), where we first estimate equation 2B using the full sample and then estimate equation 3B including only those firms that use bank credit. Again, the estimated correlation between the error terms in the two equations is statistically indistinguishable from zero, indicating that sample-selection bias is not present when we estimate equation $3 \mathrm{~B}$ with a simple weighted-least-squares model. 
The amount of Bank Credit Used is negatively related to firm size as measured by the $\log$ of Sales; to financial slack as measured by the ratio of Cash to assets; to Tangible Assets as measured by the sum of land and depreciable assets scaled by total assets; and is positively related to profitability as measured by ROA and to firm opaqueness (younger) as measured by $\log$ of Firm Age. These results offer conflicting evidence regarding the pecking-order theory and trade-off theory. The results with respect to financial slack and firm opaqueness are supportive of the pecking-order theory; whereas the results with respect to profitability are supportive of the trade-off theory. The negative sign on Tangible Assets is inconsistent with both theories and with results from prior research, including Cole (2008).

None of the owner characteristics are consistently significant in explaining the amount of bank credit used, with inconsistent results across the three surveys. Education as proxied by owners with a graduate degree is consistently negative in explaining the amount of bank credit used, but lacks statistical significance in 1993 and 2003.

By industry, the amount of bank credit used is greater for transportation firms and lesser for retail-trade firms as compared to the omitted category of construction firms. In general, these results are consistent with those reported by Cole (2008), who also examined the ratio of total loans to total assets from the SSBFs; however, he measured total loans using the balance-sheet values rather than the values from the detailed loan information.

In summary, the results from analyzing the amount of bank credit used are problematic, at best. They conflict with findings of previous research, including studies that use the SSBFs. We speculate that these conflicts arise from our decision to estimate the amount of bank credit from the detailed information on loans reported by the firm rather than by the amount of loans reported on the balance sheet. The correlation between these two measures was only in the range 
of $0.5-0.6$ for the three SSBFs analyzed. However, our use of this proxy for bank credit is consistent with our use of the firm's answers to these questions in calculating whether or not a firm used bank credit, which is a more important analysis variable for this study.

\section{Summary and Conclusions}

In this study, we use data from the 1993, 1998 and 2003 Surveys of Small Business Finances to provide new information about the use of credit by small businesses in the U.S. More specifically, we first analyze firms that do and do not use credit, i.e., leveraged and unleveraged firms; and then analyze how firms that do use credit (leveraged firms) allocate their liabilities between bank credit (obtained from financial institutions) and trade credit (obtained from suppliers), in order to shed new light upon these critically important issues. We utilize data from the Federal Reserve Board's 1993, 1998 and 2003 SSBFs - a series of nationally representative samples of small U.S. businesses - to estimate a Heckman selection model, where the manager of a firm first decides if it needs credit, and then decides from where to obtain this credit—-from financial institutions (in the form of bank credit) or from suppliers (in the form of trade credit).

We find that one in five small firms uses no credit, one in five uses trade credit only, one five uses bank credit only, and two in five use both bank credit and trade credit. From these results it is clear that trade credit is more than just a substitute for bank credit, as 40 percent of small businesses use both types of credit simultaneously. These results are consistent across the three SSBFs we examine—1993, 1998 and 2003.

When compared to firms that use credit, we find that use no credit firms are significantly smaller, more profitable, more liquid and of better credit quality, but hold fewer tangible assets. We also find that use no credit firms are more likely to be found in the services industries and in 
the wholesale and retail-trade industries. In general, these findings are consistent with the pecking-order theory of firm capital structure.

Use trade credit firms are larger, more liquid, of worse credit quality, and less likely to be a firm that primarily provides services. Among, use trade credit firms, the amount of trade credit used as a percentage of assets is positively related to liquidity and negatively related to credit quality and is lower at firms that primarily provide services. In general, these results are consistent with the financing-advantage theory of trade credit.

Use bank credit firms are larger, less profitable, less liquid and more opaque as measured by firm age, i.e., younger. Among use bank credit firms, the amount of bank credit used as a percentage of assets is positively related firm liquidity and to firm opacity as measured by firm age. Again, these results are generally consistent with the pecking-order theory of capital structure, but with some notable exceptions. The amount of Bank Credit Used is positively related to profitability and negatively related to tangibility of assets, both in contradiction to the pecking-order theory.

We contribute to the literature on the availability of credit in at least two important ways. First, we document that one in five small U.S. firms uses no bank credit or trade credit, and provide the first rigorous analysis of the differences in these firms and other small U.S. firms that do use credit. ${ }^{15}$ A better understanding of why one in five small U.S. firms uses no credit should provide both academics and policymakers with new insights into why these firms choose not to participate in the credit markets, and what are the economic and financial consequences for such firms. Our new evidence also should provide guidance to policymakers regarding how to tailor

${ }^{15}$ Other researchers (e.g., Chakravarty and Yilmazer (2008) and Cole (2009)) have examined differences in firms that do and do not apply for credit, but not differences in firms that do or do not use credit. According to Cole (2009), a substantial portion of firms that do not apply for credit reports substantial debt in their capital structure. 
economic and tax policies as well as regulations to encourage unleveraged firms that are credit constrained to enter the credit markets.

Second, for those small U.S. firms that do participate in the credit markets, we provide new evidence regarding factors that determine their use of trade credit and bank credit, and whether these two types of credit are substitutes (Meltzer, 1960) or complements (Burkart and Ellingsen, 2004). Our evidence strongly suggests that they are complements, as two in five small U.S. firms consistently use credit of both types. This is not surprising because trade credit is primarily short-term whereas bank credit is typically longer-term.

This evidence has important implications for monetary policy, as trade credit has been theorized to be a shock absorber for small firms during times of tight money. If trade credit is a complement rather than a substitute for bank credit, then policymakers need to take this into account when tightening monetary policy by making available to small businesses alternative sources of financing.

Our evidence also has important implications for fiscal policy, as the administration and Congress look for ways to stimulate credit provided to small business lending. Existing proposals focus exclusively on bank lending while totally ignoring trade credit, which is an equally important source of capital for small businesses. Complementary proposals should explore how to expand trade credit offered by supplier as well as how to expand bank credit offered by financial institutions. Provision of new tax credits for suppliers that expand their lending is one path by which to accomplish this goal. Provision of TARP funds to suppliers is another. Yet no one is offering such proposals.

As the first rigorous analysis of small U.S. businesses that choose to use no bank credit and no trade credit, this study provides both academics and policymakers with new insights into 
the availability of credit to small firms, and how to tailor macroeconomic policies, regulations and taxes to help small businesses obtain needed credit and reach their optimal capital structures. Policies designed to help these firms improve their capitalization should lead to higher growth in both employment and output (GDP). 


\section{REFERENCES}

Aghion, P. and Howitt, P. 1988. Endogenous Growth Theory. Massachusetts Institute of Technology Press. Cambridge, MA.

Ang, J., Cole, R., Lin, J. 2000. Agency costs and ownership structure. The Journal of Finance $55,81-106$

Berger, A. and Udell, G. 1995. Relationship lending and lines of credit in small firm finance. Journal of Business 68, 351-381.

Berger, A., and Udell, G. 1998. The economics of small business finance: The roles of private equity and debt markets in the financial growth cycle, Journal of Banking \& Finance 22 (6-8), $613-673$.

Berger, A., and Udell, G. 2006. A more complete framework for SME finance, Journal of Banking \& Finance 30(11), 2945-2966.

Berger, A., Frame, S., and Miller, N. 2005. Credit scoring and the availability, price and risk of small business credit. Journal of Money, Credit and Banking 37(2), 191-222.

Berger, A., Miller, N., Rajan, R., Stein, J., and Petersen, M. 2005. Does function follow organizational form? Evidence from the lending practices of large and small banks." Journal of Financial Economics 76 (2): 237-269.

Biais, B, and Gollier, C. 1997. Trade credit and credit rationing. Review of Financial Studies 10, 903-937.

Bitler, M., Robb, A., and Wolken, J. 2001. Financial Services Used by Small Businesses: Evidence from the 1998 Survey of Small Business Finances. Federal Reserve Bulletin 87 (April), 183-205.

Blanchflower, D., Levine, P., and Zimmerman, D. 2003. Discrimination in the small business credit narket. Review of Economics and Statistics 84 (4), 930-943.

Burkart, M., Ellingsen, T. 2004. In-kind finance: A theory of trade credit. American Economic Review 94(3), 569-590.

Carey, M., Post, M., and Sharpe, S. Does corporate lending by banks and finance companies differ? Evidence on specialization in private debt contracting. Journal of Finance, 53 (1998), 845-878.

Cavalluzzo, K., and Cavalluzzo, L. 1998. Market structure and discrimination: The case of small businesses. Journal of Money, Credit and Banking 30 (4), 771-92.

Cavalluzzo, K., Cavalluzzo, L., and Wolken, J. 2002. Competition, small business financing, and discrimination: Evidence From a new survey. Journal of Business 75(4), 641-679. 
Cavalluzzo, K., and Wolken, J. 2005. Small business loan turndowns, personal wealth and discrimination. Journal of Business 78(6): 2153-2178.

Chakraborty, A., and Hu, C. 2006. Lending relationships in line-of-credit and non-line-ofcredit loans: Evidence from collateral use in small business. Journal of Financial Intermediation. 15 (1), 86-107.

Chakravarty, A. Yilmazer, T. 2009. A multi-stage model of loans and the role of relationships. Financial Management, 38(4), 781-816.

Claessens, S., Djankov, S., and Lang, L. 2000. The separation of ownership and control in east asian corporations. Journal of Finance 58, 81-112.

Cole, R. 1998. The importance of relationships to the availability of credit. Journal of Banking and Finance 22, 959-997.

Cole, R. 2008. What do we know about the capital structure of privately held firms? Evidence from the Surveys of Small Business Finance. U.S. Small Business Administration Economic Research Study No. 324. Available at http://www.sba.gov/advo/research/rs324.pdf

Cole, R. 2009. Who needs credit and who gets credit? Evidence from the Surveys of Small Business Finance. U.S. Small Business Administration Economic Research Study. Available at http://www.sba.gov/advo/research/09finfocus.pdf.

Cole, R., Goldberg, L. and White, L. 2004. Cookie-cutter versus character: The micro structure of small-business lending by large and small banks. Journal of Financial and Quantitative Analysis 39, 227-251.

Cole, R., Wolken, J., 1995. Financial services used by small businesses: Evidence from the 1993 National Survey of Small Business Finances. Federal Reserve Bulletin 81 (July), 630-67.

Coleman, S. 2002. The borrowing experience of black and Hispanic-owned small firms: Evidence from the 1998 Survey of Small Business Finances. The Academy of Entrepreneurship Journal 8 (1), 1-20.

Cuñat, V. 2007. Trade Credit: Suppliers as Debt Collectors and Insurance Providers. Review of Financial Studies 20, 492-527.

Elliehausen, G., Wolken, J. 1990. Banking markets and the use of financial services by small and medium-sized businesses. Federal Reserve Bulletin 76 (October), 801-817.

Ferris, J. 1981. A transaction theory of trade credit use. Quarterly Journal of Economics 94(2), 243-270. 
Fisman, R. and Love, I. Trade credit, financial intermediation and industry growth. Journal of Finance 58, 353-374.

Frank, M. and and Goyal, V. 2007. Capital structure decisions: What factors are reliably important? working paper.

Greene, W. 2003. Econometric Analysis, 5th Ed. Upper Saddle River, Prentice Hall.

Heckman, J. 1979. Sample selection bias as a specification error. Econometrica 47, 153-161.

Huyghebaert, N., Van de Gucht, L. and Van Hulle, C. 2007. The choice between bank debt and trade credit in business start-ups. Small Business Economics 29, 435-452.

Jensen, M., Meckling, W. 1976. Theory of the firm: Managerial behavior agency costs and capital structure. Journal of Financial Economics 3, 305-360.

King, R., Levine, R. 1993a. Finance and growth: Schumpeter might be right. Quarterly Journal of Economics 108, 717-738.

King, R., Levine, R. 1993b. Finance, entrepreneurship, and growth: theory and evidence. Journal of Monetary Economics 32, 513-542.

Love, I., Preve, L., and Sarria-Allende, V. 2007. Trade credit and bank credit: Evidence from recent financial crises. Journal of Financial Economics 83, 453-469.

Mach, T., Wolken, J. 2006. Financial services used by small businesses: Evidence from the 2003 Survey of Small Business Finance. Federal Reserve Bulletin Oct 2006, 167-195.

Meltzer, A. 1960. Mercantile credit, monetary policy and the size of firms. Review of Economics and Statistics 42(4), 429-436.

Mian, S., Smith, C. 1992. Accounts Receivable Management Policy: Theory and Evidence. The Journal of Finance 47, 169-200.

$\mathrm{Ng}, \mathrm{C}$., Smith, J. and Smith, R. 1999. Evidence on the determinants of credit terms used in interfirm trade credit. Journal of Finance 54, 1109-1129.

Nilsen, J. 2002. Trade credit and the bank lending channel. Journal of Money, Credit and Banking 34(1), 226-253.

Petersen, M., Rajan, R. 1994. The benefits of lending relationships: Evidence from small business data. Journal of Finance, 46(1), 3-37.

Petersen, M., Rajan, R. 1997. Trade Credit: Theories and Evidence. Review of Financial Studies 10(3), 661-691. 
Rajan, R., Zingales, L. 1998. Financial dependence and growth. American Economic Review 88, 559-586.

Robb, A.M. 2002. Small business financing: Differences between young and old firms. Journal of Entrepreneurial Finance and Business Ventures 7, 45-65.

Smith, J. 1987. Trade credit and informational asymmetry. Journal of Finance 42, 863-872.

Schumpeter, J. 1934. The Theory of Economic Development. Translated by Redvers Opie. Harvard University Press, Cambridge, MA.

Van de Ven, W., Van Praag, B., The demand for deductibles in private health insurance: A probit model with sample selection. Journal of Econometrics 17, 229-252.

Wendt, P. 1947. The Availability of Capital to Small Businesses in California. The Journal of Finance 2 (2), 43-54. 


\section{Table 1: \\ Definitions of Analysis Variables}

\section{Dependent Variables: \\ Use Credit \\ Use Trade Credit \\ Use Bank Credit \\ Amount of Bank Credit \\ Amount of Trade Credit}

\section{Explanatory Variables:}

Firm Characteristics

Sales

Assets

Cash

Current Assets

Tangible Assets

Growth Positive

Corporation

Firm Age

Firm Delinquency

Rural

Owner Characteristics

Owner Age

Female

Asian

Black

Hispanic

College Degree

Graduate Degree

Owner's Delinquent Obligations

Ownership Percentage

\section{Industrial Classification}

Construction

Primary Mfg

Secondary Mfg

Transportation

Wholesale

Retail

Insurance/Real Estate

Business Services

Professional Services
Firm reported that it used bank or trade credit during reference year.

Firm reported that it used trade credit during reference year.

Firm reported that it used bank credit during reference year.

Sum of outstanding balances of all loans during the reference year.

Amount of accounts payable in the reference year.

Annual sales revenues

Total Assets

Cash

Sum of accounts receivable, inventory and other current assets.

Sum of land and depreciable assets

Sales Growth is positive.

Firm is organized as an S-corporation or C-corporation.

Years since firm was established.

Firm has been delinquent on a business obligation during past three years.

Firm is located in a rural area, i.e., outside of an MSA.

Age of primary owner.

Primary owner is female.

Primary owner is Asian.

Primary owner is black.

Primary owner is Hispanic.

Primary owner has a college degree.

Primary owner has a graduate degree.

Owner has been delinquent on a personal obligation during past three years.

Ownership percentage of primary owner.

Firm is in SIC $10-19$

Firm is in SIC 20 - 29

Firm is in SIC 30 - 39

Firm is in SIC 40 - 49

Firm is in SIC $50-51$

Firm is in SIC $52-59$

Firm is in SIC 60 - 69 (excludes financial institutions)

Firm is in SIC $70-79$

Firm is in SIC $80-89$ 
Table 2:

Distribution of Firms by Use of Trade Credit and Bank Credit

1993

1998

2003

No Credit

Observations (unweighted)

656

622

614

Observations (weighted, millions)

0.911

1.087

1.239

Percentage (weighted)

$18.6 \%$

$21.5 \%$

$21.1 \%$

\section{Trade Credit Only}

Observations (unweighted)

828

662

619

Observations (weighted, millions)

1.116

1.171

1.074

Percentage (weighted)

$22.8 \%$

$23.1 \%$

$18.3 \%$

\section{Bank Credit Only}

Observations (unweighted)

761

506

Observations (weighted, millions)

0.866

0.811

1.083

Percentage (weighted)

$17.7 \%$

$16.0 \%$

$18.5 \%$

\section{Trade and Bank Credit}

Observations (unweighted)

1,917

1,395

1,765

Observations (weighted, millions)

1.991

1.993

2.466

Percentage (weighted)

$40.8 \%$

$39.4 \%$

$42.1 \%$

\section{Total}
Observations (unweighted)
Observations (weighted, millions)
Percentage (weighted)

4,162

4.885

3,185

3,568

$100.0 \%$

5.062

5.862

$100.0 \%$

$100.0 \%$

Data are from the 1993, 1998 and 2003 SSBFs. Firms are classified as using no credit if the firm reported that is used neither bank credit nor trade credit during the survey year. Firms are classified as using trade credit only if the firm reported that it used trade credit but did not use bank credit during the survey year. Firms are classified as using bank credit only if the firm reported that it used bank credit but did not use trade credit during the survey year. Firms are classified as using trade and bank credit if the firm reported that it used trade credit and used bank credit during the survey year. Weighted statistics are obtained by using the survey sampling weights, which are needed because the surveys are not simple random samples. 
Table 3A:

Descriptive Statistics for Firms that Use and Do Not Use Credit, 1993 SSBF

\section{Variable}

Obs.

Assets

Sales

ROA

Cash

Current Assets

Tangible Assets

Sales Growth is Positive

Corporation

Firm Age

D\&B Credit Score

Firm Delinquency

Firm located in MSA

Owner Age

Owner Experience

Owner is Female

Owner is Asian

Owner is Black

Owner is Hispanic

Owner has College Degree

Owner has Graduate Degree

Owner Percentage Ownership

Owner Delinquency

Construction

Primary Mfg

Secondary Mfg

Transportation

Wholesale

Retail

Insurance/Real Estate

Business Services
All Firms No Credit Use Credit

\author{
4,162
}

293,880

566,103

0.601

0.186

0.329

0.399

0.420

0.480

14.114

N/A

0.191

0.786

49.295

18.702

0.209

0.036

0.030

0.043

0.260

0.202

81.509

0.137

0.143

0.039

0.041

0.027

0.082

0.217

0.068

0.215

0.168
656

128,089

228,656

0.875

0.278

0.280

0.408

0.420

0.326

14.937

N/A

0.087

0.814

51.495

19.360

0.235

0.048

0.036

0.044

0.214

0.240

88.018

0.092

0.085

0.006

0.019

0.025

0.056

0.182

0.098

0.304

0.224
3,506

331,914

643,517

0.539

0.165

0.340

0.397

0.420

0.515

13.925

N/A

0.215

0.780

48.790

18.552

0.203

0.033

0.028

0.043

0.271

0.193

80.016

0.147

0.157

0.046

0.046

0.028

0.088

0.224

0.061

0.194

0.155
Difference t-test

$\begin{array}{rrr}-203,826 & -7.93 & \mathbf{a} \\ -414,861 & -13.45 & \mathbf{a} \\ 0.337 & 4.93 & \mathbf{a} \\ 0.112 & 8.54 & \mathbf{a} \\ -0.060 & -4.26 & \mathbf{a} \\ 0.011 & 0.74 & \end{array}$

$0.001 \quad 0.04$

$\begin{array}{rrr}-0.190 & -8.78 & \mathbf{a}\end{array}$

$\begin{array}{lll}1.012 & 1.86 & \mathbf{c}\end{array}$

$\begin{array}{lll}-0.128 & -9.29 & \mathbf{a}\end{array}$

$\begin{array}{llll}0.034 & 1.90 & \mathbf{c}\end{array}$

$\begin{array}{lll}2.705 & 4.92 & \mathbf{a}\end{array}$

$0.808 \quad 1.47$

$\begin{array}{llll}0.033 & 1.70 & \mathbf{c}\end{array}$

$0.015 \quad 1.60$

$0.007 \quad 0.88$

$0.001 \quad 0.06$

$\begin{array}{rrr}-0.057 & -2.98 & \mathbf{a}\end{array}$

$\begin{array}{lll}0.047 & 2.46 & \mathbf{b}\end{array}$

$\begin{array}{lll}8.002 & 7.66 & \mathbf{a}\end{array}$

$\begin{array}{rrr}-0.055 & -4.06 & \mathbf{a}\end{array}$

$\begin{array}{lll}-0.071 & -5.35 & \mathbf{a}\end{array}$

$\begin{array}{lll}-0.040 & -8.29 & \mathbf{a}\end{array}$

$\begin{array}{lll}-0.027 & -3.97 & \mathbf{a}\end{array}$

$-0.003-0.35$

$-0.032 \quad-2.94 \quad \mathbf{a}$

$-0.042 \quad-2.37 \quad$ b

$0.037 \quad 2.77 \quad \mathbf{a}$

$0.109 \quad 5.30 \quad \mathbf{a}$

$0.069 \quad 3.67 \quad$ a

Data are from the 1993 SSBF. Firms are classified as using credit if the firm reported that is used either bank credit or trade credit during 1993. Means are presented for all firms and separately for firms that use credit and firms that use no credit. In the last column is the t-statistic for a test of significant differences in the means of the two groups.

$\mathrm{a}, \mathrm{b}$ and $\mathrm{c}$ indicate statistical significance at the $0.01,0.05$ and 0.10 levels, respectively. 
Table 3B:

Descriptive Statistics for Firms that Use and Do Not Use Credit, 1998 SSBF

\section{Variable}

Obs.

Assets

Sales

ROA

Cash

Current Assets

Tangible Assets

Sales Growth is Positive

Corporation

Firm Age

D\&B Credit Score

Firm Delinquency

Firm located in MSA

Owner Age

Owner Experience

Owner is Female

Owner is Asian

Owner is Black

Owner is Hispanic

Owner has College Degree

Owner has Graduate Degree

Owner Percentage Ownership

Owner Delinquency

Construction

Primary Mfg

Secondary Mfg

Transportation

Wholesale

Retail

Insurance/Real Estate

Business Services

\section{All Firms No Credit Use Credit}

3,164

257,653

524,774

0.843

0.236

0.322

0.374

0.399

0.427

13.145

3.008

0.136

0.797

50.057

18.062

0.241

0.043

0.041

0.057

0.300

0.182

85.668

0.127

0.118

0.037

0.046

0.036

0.069

0.193

0.065

0.250

0.184
621

66,911

155,316

1.101

0.348

0.279

0.310

0.356

0.258

12.152

2.938

0.045

0.824

51.128

17.043

0.312

0.052

0.059

0.081

0.290

0.199

90.987

0.106

0.043

0.030

0.025

0.048

0.049

0.187

0.087

0.270

0.259
2,543

309,928

626,028

0.772

0.206

0.334

0.391

0.411

0.474

13.418

3.027

0.161

0.789

49.764

18.341

0.221

0.041

0.036

0.051

0.303

0.178

84.210

0.132

0.139

0.039

0.051

0.033

0.074

0.194

0.058

0.245

0.164
Difference t-test

$\begin{array}{rrr}-243,017 & -14.44 & \mathbf{a} \\ -470,712 & -14.81 & \mathbf{a} \\ 0.329 & 4.55 & \mathbf{a} \\ 0.142 & 9.17 & \mathbf{a} \\ -0.055 & -3.44 & \mathbf{a} \\ -0.082 & -4.89 & \mathbf{a} \\ -0.055 & -2.46 & \mathbf{b} \\ -0.216 & -10.37 & \mathbf{a} \\ -1.266 & -2.52 & \mathbf{b} \\ -0.089 & -2.26 & \mathbf{b} \\ -0.116 & -10.27 & \mathbf{a} \\ 0.035 & 1.95 & \mathbf{c} \\ 1.364 & 2.45 & \mathbf{b} \\ -1.298 & -2.28 & \mathbf{b} \\ 0.090 & 4.27 & \mathbf{a} \\ 0.011 & 1.08 & \\ 0.023 & 2.16 & \mathbf{b} \\ 0.031 & 2.48 & \mathbf{b} \\ -0.013 & -0.61 & \end{array}$

$0.021 \quad 1.16$

$\begin{array}{rrr}6.777 & 7.07 & \mathbf{a}\end{array}$

$\begin{array}{rrr}-0.026 & -1.79 & \mathbf{c}\end{array}$

$\begin{array}{lll}-0.096 & -8.77 & \mathbf{a}\end{array}$

$-0.009 \quad-1.16$

$\begin{array}{lll}-0.027 & -3.42 & \mathbf{a}\end{array}$

$0.015 \quad 1.55$

$\begin{array}{lll}-0.025 & -2.42 & \mathbf{b}\end{array}$

$-0.008 \quad-0.42$

$\begin{array}{lll}0.029 & 2.28 & \text { b }\end{array}$

$0.025 \quad 1.20$

$\begin{array}{lll}0.095 & 4.80 \quad \mathbf{a}\end{array}$

Data are from the 1998 SSBF. Firms are classified as using credit if the firm reported that is used either bank credit or trade credit during 1998. Means are presented for all firms and separately for firms that use credit and firms that use no credit. In the last column is the t-statistic for a test of significant differences in the means of the two groups.

$\mathrm{a}, \mathrm{b}$ and $\mathrm{c}$ indicate statistical significance at the $0.01,0.05$ and 0.10 levels, respectively. 
Table 3C:

Descriptive Statistics for Firms that Use and Do Not Use Credit, 2003 SSBF

\section{Variable}

Obs.

Assets

Sales

ROA

Cash

Current Assets

Tangible Assets

Sales Growth is Positive

Corporation

Firm Age

D\&B Credit Score

Firm Delinquency

Firm located in MSA

Owner Age

Owner Experience

Owner is Female

Owner is Asian

Owner is Black

Owner is Hispanic

Owner has College Degree

Owner has Graduate Degree

Owner Percentage Ownership

Owner Delinquency

Construction

Primary Mfg

Secondary Mfg

Transportation

Wholesale

Retail

Insurance/Real Estate

Business Services

\section{All Firms No Credit Use Credit}

3,623

340,380

624,307

0.557

0.231

0.306

0.328

0.406

0.450

14.190

3.610

0.157

0.793

51.506

19.610

0.263

0.044

0.039

0.044

0.291

0.208

81.987

0.121

0.117

0.031

0.040

0.039

0.057

0.187

0.067

0.253

0.210
618

96,680

179,933

0.735

0.404

0.294

0.278

0.321

0.271

12.973

3.459

0.060

0.834

52.337

17.263

0.392

0.056

0.060

0.049

0.319

0.237

86.755

0.098

0.057

0.018

0.019

0.020

0.043

0.168

0.081

0.306

0.288

3,005

404,700

741,592

0.510

0.185

0.310

0.341

0.428

0.497

14.512

3.650

0.182

0.782

51.287

20.230

0.229

0.041

0.034

0.042

0.283

0.201

80.728

0.127

0.133

0.034

0.045

0.044

0.060

0.191

0.064

0.239

0.189
Difference t-test

$\begin{array}{lll}-308,020 & -15.01 \quad \mathbf{a} \\ -561,659 & -17.58 & \text { a }\end{array}$

$\begin{array}{llll}-561,659 & -17.58 \quad \mathbf{a}\end{array}$

$\begin{array}{lll}0.226 & 4.81 \quad \mathbf{a}\end{array}$

$\begin{array}{lll}0.219 & 12.75 \quad \mathbf{a}\end{array}$

$-0.016 \quad-0.98$

$\begin{array}{lll}-0.062 & -3.77 \quad \mathbf{a}\end{array}$

$\begin{array}{lll}-0.107 & -4.72 & \mathbf{a}\end{array}$

$\begin{array}{lll}-0.225 & -10.36 \quad \mathbf{a}\end{array}$

$\begin{array}{lll}-1.538 & -2.98 & \mathbf{a}\end{array}$

$\begin{array}{lll}-0.191 & -3.15 & \mathbf{a}\end{array}$

$\begin{array}{lll}-0.122 & -9.62 & \mathbf{a}\end{array}$

$\begin{array}{lll}0.052 & 2.86 \quad \mathbf{a}\end{array}$

$\begin{array}{lll}1.050 & 1.83 \quad \mathbf{c}\end{array}$

$\begin{array}{lll}-2.967 & -5.12 & \mathbf{a}\end{array}$

$\begin{array}{lll}0.163 & 7.10 & \mathbf{a}\end{array}$

$0.014 \quad 1.32$

$\begin{array}{lll}0.026 & 2.35 & \mathbf{b}\end{array}$

$\begin{array}{ll}0.006 & 0.63\end{array}$

$\begin{array}{ll}0.036 & 1.59\end{array}$

$\begin{array}{lll}0.036 & 1.78 \quad \text { c }\end{array}$

$\begin{array}{rrr}6.026 & 5.50 \quad \mathbf{a}\end{array}$

$\begin{array}{lll}-0.029 & -1.97 & \mathbf{b}\end{array}$

$\begin{array}{lll}-0.076 & -6.36 & \mathbf{a}\end{array}$

$\begin{array}{lll}-0.016 & -2.42 & \mathbf{b}\end{array}$

$\begin{array}{lll}-0.026 & -3.58 & \mathbf{a}\end{array}$

$\begin{array}{lll}-0.024 & -3.27 & \mathbf{a}\end{array}$

$\begin{array}{lll}-0.018 & -1.78 \quad \text { c }\end{array}$

$-0.024 \quad-1.30$

$0.017 \quad 1.30$

$\begin{array}{lll}0.068 & 3.09 & \mathbf{a}\end{array}$

$0.098 \quad 4.61 \quad$ a

Data are from the 2003 SSBF. Firms are classified as using credit if the firm reported that is used either bank credit or trade credit during 2003. Means are presented for all firms and separately for firms that use credit and firms that use no credit. In the last column is the t-statistic for a test of significant differences in the means of the two groups.

$\mathrm{a}, \mathrm{b}$ and $\mathrm{c}$ indicate statistical significance at the $0.01,0.05$ and 0.10 levels, respectively. 
Table 4:

Determinants of the Use of Credit

\begin{tabular}{|c|c|c|c|c|c|c|c|c|c|}
\hline \multirow[b]{3}{*}{ Variable } & \multicolumn{2}{|c|}{1993} & & \multicolumn{2}{|c|}{1998} & \multicolumn{4}{|c|}{2003} \\
\hline & Margina & & & Margina & & & Margina & & \\
\hline & Effect & t-stat & & Effect & t-stat & & Effect & t-stat & \\
\hline Intercept & & 2.23 & b & & 1.66 & c & & 1.58 & \\
\hline $\log$ of Sales & 0.048 & 13.56 & $\mathbf{a}$ & 0.041 & 12.76 & $\mathbf{a}$ & 0.032 & 12.41 & \\
\hline $\mathrm{ROA}$ & -0.016 & -4.57 & $\mathbf{a}$ & -0.025 & -5.41 & $\mathbf{a}$ & -0.030 & -4.64 & $a$ \\
\hline Cash & -0.153 & -7.14 & $\mathbf{a}$ & -0.212 & -9.22 & $\mathbf{a}$ & -0.219 & -11.54 & a \\
\hline Tangible Assets & -0.062 & -3.54 & $\mathbf{a}$ & -0.072 & -3.60 & $\mathbf{a}$ & -0.050 & -2.79 & 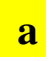 \\
\hline ales Growth is $\mathrm{F}$ & -0.003 & -0.27 & & 0.007 & 0.58 & & 0.024 & 2.20 & \\
\hline Corporation & -0.010 & -0.82 & & 0.042 & 2.81 & $\mathbf{a}$ & 0.029 & 2.39 & \\
\hline log of Firm Age & -0.010 & -1.02 & & -0.014 & -1.34 & & -0.012 & -1.60 & \\
\hline irm Delinquency & 0.057 & 3.31 & $\mathbf{a}$ & 0.135 & 4.86 & $\mathbf{a}$ & 0.008 & 2.05 & b \\
\hline MSA & -0.041 & -3.20 & $\mathbf{a}$ & -0.018 & -1.14 & & -0.022 & -1.62 & \\
\hline $\log$ of Owne & -0.112 & -4.06 & $\mathbf{a}$ & -0.075 & -2.34 & b & -0.075 & -2.70 & $\mathbf{a}$ \\
\hline $\log$ of Owne & 0.013 & 1.13 & & 0.042 & 3.46 & $\mathbf{a}$ & 0.044 & 4.34 & $\mathbf{a}$ \\
\hline Owner is Female & 0.011 & 0.90 & & -0.007 & -0.52 & & -0.037 & -3.32 & $\mathbf{a}$ \\
\hline Owner is Asian & -0.044 & -1.86 & c & -0.022 & -0.79 & & -0.047 & -1.95 & c \\
\hline Owner is Black & -0.016 & -0.57 & & -0.024 & -0.87 & & -0.030 & -1.27 & \\
\hline Owner is Hispanic & -0.001 & -0.04 & & -0.057 & -2.46 & b & -0.025 & -1.04 & \\
\hline Owner has Colle & 0.026 & 2.06 & b & 0.004 & 0.27 & & -0.022 & -1.74 & $\mathbf{c}$ \\
\hline Owner has G & -0.004 & -0.26 & & 0.011 & 0.58 & & 0.004 & 0.24 & \\
\hline Owner Percentage Ownership & -0.0006 & -2.44 & b & -0.0004 & -1.36 & & -0.0005 & -2.03 & b \\
\hline Owner Delinquency & 0.033 & 1.89 & c & -0.023 & -1.07 & & 0.030 & 1.78 & c \\
\hline Primary Mfg & 0.155 & 2.70 & $\mathbf{a}$ & -0.138 & -3.19 & $\mathbf{a}$ & -0.008 & -0.19 & \\
\hline Secondary Mf & 0.013 & 0.34 & & -0.102 & -2.35 & b & -0.017 & -0.44 & \\
\hline Transportation & -0.095 & -2.89 & $\mathbf{a}$ & -0.256 & -6.49 & $\mathbf{a}$ & 0.001 & 0.02 & \\
\hline Wholesale & -0.064 & -2.52 & b & -0.176 & -4.67 & $\mathbf{a}$ & -0.070 & -2.18 & b \\
\hline Retail & -0.082 & -4.22 & $\mathbf{a}$ & -0.196 & -6.60 & $\mathbf{a}$ & -0.087 & -3.69 & $\mathbf{a}$ \\
\hline Insurance/Real Estate & -0.118 & -5.15 & $\mathbf{a}$ & -0.216 & -6.44 & $\mathbf{a}$ & -0.085 & -3.09 & $\mathbf{a}$ \\
\hline Business Services & -0.095 & -5.23 & $\mathbf{a}$ & -0.150 & -5.33 & $\mathbf{a}$ & -0.078 & -3.55 & $\mathbf{a}$ \\
\hline Professional Services & -0.098 & -4.69 & $\mathbf{a}$ & -0.219 & -7.27 & $\mathbf{a}$ & -0.099 & -4.40 & $\cdots$ \\
\hline
\end{tabular}

Results from a weighted univariate probit model used to explain the determinants of the use of credit by privately held firms. Data are from the 1993, 1998 and 2003 SSBFs. Firms are classified as using credit if the firm reported that is used either bank credit or trade credit during the survey year. Variable definitions appear in Table 1.

$\mathrm{a}, \mathrm{b}$ and $\mathrm{c}$ indicate statistical significance at the $0.01,0.05$ and 0.10 levels, respectively. 


\section{Table 5:}

Determinants of the Use of Trade Credit

\begin{tabular}{|c|c|c|c|c|c|c|c|c|}
\hline \multirow[b]{2}{*}{ Variable } & \multicolumn{2}{|c|}{1993} & & \multicolumn{2}{|c|}{1998} & & & $\begin{array}{l}003 \\
\text { al }\end{array}$ \\
\hline & Effect & t-stat & & Effect & t-stat & & Effect & t-stat \\
\hline Intercept & & 0.48 & & & -0.99 & & & -0.58 \\
\hline $\log$ of Sales & 0.008 & 1.71 & c & 0.012 & 3.09 & $\mathbf{a}$ & 0.013 & $3.62 \mathrm{a}$ \\
\hline ROA & -0.001 & -0.17 & & -0.001 & -0.08 & & -0.014 & -1.50 \\
\hline Cash & 0.126 & 3.55 & $\mathbf{a}$ & 0.143 & 4.25 & 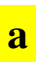 & 0.180 & $6.13 \mathrm{a}$ \\
\hline Current Assets & 0.160 & 5.98 & $\mathbf{a}$ & 0.162 & 5.97 & $\mathbf{a}$ & 0.075 & $3.11 \mathrm{a}$ \\
\hline Sales Growth is $\mathrm{P}$ & -0.023 & -1.55 & & 0.004 & 0.26 & & 0.035 & $2.38 \mathrm{~b}$ \\
\hline Corporation & -0.043 & -2.65 & $\mathbf{a}$ & 0.062 & 3.50 & a & 0.072 & $4.64 \mathrm{a}$ \\
\hline $\log 0$ & -0.004 & -0.29 & & -0.007 & -0.52 & & 0.032 & $3.17 \mathrm{a}$ \\
\hline irm Delinquency & 0.099 & 4.63 & a & 0.136 & 4.92 & $\mathbf{a}$ & 0.007 & 1.34 \\
\hline MSA & -0.003 & -0.21 & & 0.014 & 0.78 & & -0.035 & $-1.97 \mathbf{b}$ \\
\hline $\log$ of $\mathrm{Ow}$ & 0.011 & 0.29 & & 0.025 & 0.60 & & 0.012 & 0.30 \\
\hline $\log$ of Own & 0.027 & 1.67 & c & 0.023 & 1.47 & & 0.007 & 0.50 \\
\hline Owner is $\mathrm{F}$ & 0.005 & 0.26 & & -0.017 & -0.98 & & -0.004 & -0.25 \\
\hline Own & 0.001 & 0.02 & & -0.014 & -0.37 & & -0.004 & -0.12 \\
\hline Owne & -0.011 & -0.28 & & -0.028 & -0.75 & & -0.110 & $-3.26 \mathrm{a}$ \\
\hline Owner is Hispanic & -0.084 & -2.80 & $\mathbf{a}$ & -0.088 & -2.91 & $\mathbf{a}$ & -0.050 & -1.58 \\
\hline Owner has College Degree & 0.024 & 1.43 & & 0.023 & 1.23 & & 0.027 & 1.59 \\
\hline Owner has Graduate Degree & 0.037 & 1.76 & c & 0.020 & 0.85 & & 0.051 & $2.39 \mathrm{~b}$ \\
\hline Owner & -0.0009 & -2.98 & $\mathbf{a}$ & 0.0003 & 0.93 & & -0.0001 & -0.41 \\
\hline Owne & 0.006 & 0.28 & & -0.072 & -2.87 & & 0.012 & 0.55 \\
\hline Prima & -0.005 & -0.13 & & 0.024 & 0.45 & & -0.132 & $-2.77 \mathrm{a}$ \\
\hline Secondary Mfg & 0.003 & 0.07 & & 0.085 & 1.50 & & -0.087 & $-1.88 \mathrm{c}$ \\
\hline Transp & -0.166 & -4.17 & $\mathbf{a}$ & -0.191 & -4.58 & a & -0.217 & $-5.57 \mathbf{a}$ \\
\hline Wholesale & -0.023 & -0.68 & & -0.101 & -2.68 & & -0.138 & -3.29 a \\
\hline Reta & -0.052 & -2.07 & b & -0.071 & -2.40 & & -0.114 & -3.62 a \\
\hline Insuran & -0.205 & -6.79 & ( & -0.258 & -7.54 & & -0.264 & -7.38 \\
\hline Business Services & -0.071 & -2.93 & $\mathbf{a}$ & -0.070 & -2.60 & & -0.171 & -5.90 \\
\hline Professional Services & -0.154 & -5.62 & $\mathbf{a}$ & -0.131 & -4.27 & & -0.239 & -7.58 \\
\hline
\end{tabular}

Results from a bivariate probit selection model used to explain the determinants of the use of credit by privately held firms, conditional upon using either bank credit or trade credit. Data are from the 1993, 1998 and 2003 SSBFs. Firms are classified as using credit if the firm reported that it used trade credit during the survey year. Variable definitions appear in Table 1. $\mathrm{a}, \mathrm{b}$ and $\mathrm{c}$ indicate statistical significance at the $0.01,0.05$ and 0.10 levels, respectively. 


\section{Table 6:}

\section{Determinants of the Use of Bank Credit}

1993

\begin{tabular}{|c|c|c|c|c|c|c|c|c|c|}
\hline Variable & $\begin{array}{l}\text { Marginal } \\
\text { Effect }\end{array}$ & t-stat & & $\begin{array}{c}\text { Marginal } \\
\text { Effect }\end{array}$ & t-stat & & $\begin{array}{l}\text { Marginal } \\
\text { Effect }\end{array}$ & t-stat & \\
\hline Intercept & & 1.04 & & & 1.24 & & & 1.97 & \\
\hline $\log$ of Sales & 0.053 & 10.03 & $\mathbf{a}$ & 0.038 & 7.88 & $\mathbf{a}$ & 0.027 & 7.14 & a \\
\hline ROA & -0.031 & -5.70 & $\mathbf{a}$ & -0.017 & -2.50 & b & -0.037 & -3.77 & a \\
\hline Cash & -0.366 & -10.42 & $\mathbf{a}$ & -0.162 & -4.58 & $\mathbf{a}$ & -0.354 & -11.32 & $\mathbf{a}$ \\
\hline Tangible Assets & 0.029 & 1.19 & & 0.143 & 4.93 & $\mathbf{a}$ & -0.021 & -0.81 & \\
\hline Sales Growth is Positive & 0.074 & 4.97 & $\mathbf{a}$ & 0.010 & 0.58 & & 0.024 & 1.55 & \\
\hline Corporation & 0.013 & 0.79 & & -0.010 & -0.51 & & 0.001 & 0.08 & \\
\hline log of Firm Age & -0.031 & -2.31 & b & -0.020 & -1.36 & & -0.062 & -5.28 & $\mathbf{a}$ \\
\hline Firm Delinquency & 0.062 & 3.10 & $\mathbf{a}$ & 0.028 & 1.03 & & -0.005 & -0.90 & \\
\hline MSA & -0.029 & -1.69 & c & -0.041 & -1.90 & c & 0.026 & 1.50 & \\
\hline log of Owner Age & -0.155 & -3.97 & $\mathbf{a}$ & -0.086 & -1.76 & c & -0.052 & -1.22 & \\
\hline log of Owner Experience & 0.005 & 0.28 & & -0.011 & -0.58 & & 0.001 & 0.06 & \\
\hline Owner is Female & -0.016 & -0.94 & & -0.033 & -1.65 & c & -0.032 & -1.86 & c \\
\hline Owner is Asian & -0.058 & -1.65 & & -0.078 & -1.97 & b & -0.046 & -1.31 & \\
\hline Owner is Black & 0.040 & 0.93 & & 0.019 & 0.42 & & -0.050 & -1.30 & \\
\hline Owner is Hispanic & 0.007 & 0.20 & & 0.071 & 1.76 & c & 0.004 & 0.10 & \\
\hline Owner has College Degree & -0.034 & -2.05 & b & 0.007 & 0.33 & & -0.063 & -3.68 & a \\
\hline Owner has Graduate Degree & -0.050 & -2.41 & b & -0.005 & -0.18 & & -0.045 & -2.04 & b \\
\hline Owner Pctg. Ownership & 0.0012 & 4.14 & $\mathbf{a}$ & -0.0008 & -1.97 & b & 0.0003 & 0.91 & \\
\hline Owner Delinquency & -0.064 & -2.96 & $\mathbf{a}$ & 0.023 & 0.78 & & -0.041 & -1.82 & c \\
\hline Primary Mfg & -0.024 & -0.67 & & -0.110 & -2.37 & b & 0.043 & 0.90 & \\
\hline Secondary Mfg & -0.045 & -1.28 & & -0.097 & -2.31 & b & -0.049 & -1.26 & \\
\hline Transportation & 0.133 & 2.45 & b & 0.122 & 1.90 & c & 0.119 & 2.37 & b \\
\hline Wholesale & -0.056 & -1.93 & $\mathbf{c}$ & -0.010 & -0.25 & & -0.078 & -2.23 & b \\
\hline Retail & -0.033 & -1.44 & & -0.069 & -2.27 & b & -0.084 & -3.20 & $\mathbf{a}$ \\
\hline Insurance/Real Estate & 0.080 & 2.33 & b & 0.160 & 3.12 & $\mathbf{a}$ & 0.101 & 2.67 & $\mathbf{a}$ \\
\hline Business Services & -0.008 & -0.36 & & -0.064 & -2.27 & b & 0.007 & 0.29 & \\
\hline Professional Services & 0.065 & 2.37 & b & -0.028 & -0.84 & & 0.055 & 1.87 & $\mathbf{C}$ \\
\hline
\end{tabular}

Results from a bivariate probit selection model used to explain the determinants of the use of credit by privately held firms, conditional upon using either bank credit or trade credit. Data are from the 1993, 1998 and 2003 SSBFs. Firms are classified as using bank credit if the firm reported that it used bank credit during the survey year. Variable definitions appear in Table 1. $\mathrm{a}, \mathrm{b}$ and $\mathrm{c}$ indicate statistical significance at the $0.01,0.05$ and 0.10 levels, respectively. 
Table 7:

Determinants of the Amount of Trade Credit Used

1993

1998

2003

\begin{tabular}{|c|c|c|c|c|c|c|c|c|}
\hline Variable & Coef. & t-stat & & Coef. & t-stat & & Coef. & t-stat \\
\hline Intercept & -0.047 & -0.54 & & 0.000 & 0.00 & & 0.044 & 0.39 \\
\hline $\log$ of Sales & -0.001 & -0.45 & & 0.018 & 4.26 & $\mathbf{a}$ & 0.009 & 2.99 \\
\hline ROA & 0.008 & 2.22 & b & 0.012 & 1.80 & c & -0.005 & -0.76 \\
\hline Cash & 0.143 & 7.08 & $\mathbf{a}$ & 0.017 & 0.55 & & 0.119 & 5.32 \\
\hline Current Assets & 0.190 & 12.64 & $\mathbf{a}$ & 0.140 & 5.62 & $\mathbf{a}$ & 0.162 & 9.03 \\
\hline Sales Growth is Positive & 0.002 & 0.25 & & 0.021 & 1.44 & & 0.022 & 2.11 \\
\hline Corporation & -0.004 & -0.42 & & -0.035 & -2.09 & b & 0.041 & 3.68 \\
\hline log of Firm Age & -0.009 & -1.13 & & -0.052 & -4.19 & $\mathbf{a}$ & -0.017 & -2.31 \\
\hline Firm Delinquency & 0.039 & 3.57 & $\mathbf{a}$ & 0.122 & 5.60 & $\mathbf{a}$ & 0.025 & 6.98 \\
\hline MSA & 0.032 & 3.21 & $\mathbf{a}$ & 0.033 & 1.81 & c & 0.017 & 1.38 \\
\hline log of Owner Age & 0.031 & 1.33 & & 0.007 & 0.16 & & -0.015 & -0.51 \\
\hline $\log$ of Owner Experience & 0.013 & 1.41 & & 0.017 & 1.13 & & 0.005 & 0.43 \\
\hline Owner is Female & -0.006 & -0.57 & & -0.025 & -1.42 & & 0.001 & 0.11 \\
\hline Owner is Asian & -0.016 & -0.70 & & -0.045 & -1.22 & & -0.037 & -1.47 \\
\hline Owner is Black & 0.006 & 0.26 & & 0.002 & 0.05 & & -0.008 & -0.24 \\
\hline Owner is Hispanic & -0.019 & -0.87 & & -0.003 & -0.09 & & -0.024 & -0.89 \\
\hline Owner has College Degree & 0.005 & 0.53 & & -0.003 & -0.17 & & 0.041 & 3.44 \\
\hline Owner has Graduate Degree & -0.021 & -1.70 & c & -0.054 & -2.36 & b & 0.030 & 1.91 \\
\hline Owner Pctg. Ownership & 0.0000 & -0.21 & & -0.0002 & -0.63 & & 0.0003 & 1.51 \\
\hline Owner Delinquency & 0.050 & 3.89 & $\mathbf{a}$ & 0.073 & 2.92 & $\mathbf{a}$ & 0.050 & 3.19 \\
\hline Primary Mfg & -0.042 & -2.06 & b & -0.069 & -1.79 & c & -0.008 & -0.28 \\
\hline Secondary Mfg & -0.007 & -0.36 & & -0.143 & -4.17 & $\mathbf{a}$ & -0.034 & -1.33 \\
\hline Transportation & -0.046 & -1.61 & & -0.078 & -1.66 & c & -0.028 & -1.01 \\
\hline Wholesale & -0.007 & -0.40 & & -0.023 & -0.71 & & 0.017 & 0.74 \\
\hline Retail & -0.056 & -4.21 & $\mathbf{a}$ & -0.103 & -4.09 & $\mathbf{a}$ & -0.036 & -2.12 \\
\hline Insurance/Real Estate & -0.066 & -3.03 & $\mathbf{a}$ & -0.073 & -1.78 & c & -0.041 & -1.59 \\
\hline Business Services & -0.032 & -2.33 & b & -0.092 & -3.94 & $\mathbf{a}$ & -0.023 & -1.41 \\
\hline Professional Services & -0.085 & -5.20 & $\mathbf{a}$ & -0.106 & -3.74 & $\mathbf{a}$ & -0.087 & -4.39 \\
\hline
\end{tabular}

Results from weighted least-squares regression analysis to explain the determinants of the amount of trade credit used by privately held firms, conditional upon using trade credit. Data are from the 1993, 1998 and 2003 SSBFs. The amount of trade credit used is proxied by the value of accounts payable scaled by the value of total assets. Variable definitions appear in Table 1. $\mathrm{a}, \mathrm{b}$ and $\mathrm{c}$ indicate statistical significance at the $0.01,0.05$ and 0.10 levels, respectively. 
Table 8:

Determinants of the Amount of Bank Credit Used

1993

1998

2003

\begin{tabular}{|c|c|c|c|c|c|c|c|c|}
\hline Variable & Coeff. & t-stat & & Coef. & t-stat & & Coef. & t-stat \\
\hline Intercept & 0.984 & 7.37 & $\mathbf{a}$ & 1.201 & 7.10 & $\mathbf{a}$ & 1.188 & 4.62 \\
\hline $\mathrm{g}$ of Sales & -0.053 & -11.49 & $\mathbf{a}$ & -0.018 & -4.11 & $\mathbf{a}$ & -0.048 & -7.11 \\
\hline $\mathrm{OA}$ & .016 & 2.78 & $\mathbf{a}$ & 0.017 & 2.36 & b & 0.047 & 2.61 \\
\hline ash & 365 & -9.29 & $\mathbf{a}$ & -0.344 & -8.61 & $\mathbf{a}$ & -0.106 & -1.65 \\
\hline Tangible Assets & -0.117 & -5.33 & $\mathbf{a}$ & -0.084 & -3.49 & $\mathbf{a}$ & -0.421 & -10.53 \\
\hline Sales Growth is I & -0.006 & -0.45 & & -0.010 & -0.65 & & 0.050 & 2.01 \\
\hline Corporation & -0.004 & -0.31 & & 0.008 & 0.47 & & 0.098 & 3.65 \\
\hline g of Firm Age & -0.058 & -4.22 & $\mathbf{a}$ & -0.064 & -4.73 & $\mathbf{a}$ & -0.038 & -2.13 \\
\hline irm Delinqt & -0.005 & -0.27 & & 0.061 & 2.72 & $\mathbf{a}$ & -0.026 & -2.97 \\
\hline ISA & -0.020 & -1.37 & & -0.009 & -0.47 & & 0.089 & 2.96 \\
\hline $\mathrm{g}$ of Ow1 & 0.056 & 1.56 & & -0.051 & -1.15 & & 0.047 & 0.68 \\
\hline $\mathrm{g}$ of Ow1 & -0.007 & -0.51 & & 0.004 & 0.25 & & -0.030 & -1.19 \\
\hline Owner is Fema & 0.020 & 1.28 & & 0.027 & 1.43 & & -0.025 & -0.83 \\
\hline Owner is A & -0.012 & -0.33 & & 0.032 & 0.79 & & 0.079 & 1.29 \\
\hline Owner is Black & -0.072 & -2.03 & b & 0.002 & 0.06 & & -0.061 & -0.89 \\
\hline Owner is $\mathrm{Hi}$ & -0.038 & -1.29 & & 0.014 & 0.44 & & 0.027 & 0.47 \\
\hline Owner has & 0.008 & 0.52 & & -0.028 & -1.58 & & -0.006 & -0.22 \\
\hline Owner has Grad & -0.025 & -1.30 & & -0.058 & -2.40 & $\mathbf{b}$ & -0.018 & -0.49 \\
\hline Owner Pctg. Ownership & 0.0002 & 0.69 & & -0.0005 & -1.48 & & 0.0004 & 0.86 \\
\hline Owner Delinquency & 0.001 & 0.07 & & 0.015 & 0.62 & & 0.076 & 2.06 \\
\hline Primary Mfg & -0.013 & -0.41 & & 0.063 & 1.46 & & -0.011 & -0.16 \\
\hline Secondary Mfg & -0.071 & -2.20 & b & -0.023 & -0.60 & & -0.136 & -2.09 \\
\hline Transportation & 0.090 & 2.48 & b & 0.102 & 2.43 & b & 0.258 & 4.17 \\
\hline Wholesale & 0.000 & -0.02 & & -0.081 & -2.43 & $\mathbf{b}$ & -0.203 & -3.38 \\
\hline Retail & -0.059 & -2.91 & $\mathbf{a}$ & -0.051 & -1.95 & c & -0.112 & -2.56 \\
\hline & 0.102 & 3.54 & $\mathbf{a}$ & 0.074 & 2.16 & b & -0.107 & -1.81 \\
\hline & 012 & 0.59 & & 0.061 & 2.45 & $t$ & 0.008 & 0.19 \\
\hline & 0.033 & 137 & & 0.081 & 271 & & -0.061 & -131 \\
\hline
\end{tabular}

Results from weighted least-squares regression analysis to explain the determinants of the amount of bank credit used by privately held firms, conditional upon using bank credit. Data are from the 1993, 1998 and 2003 SSBFs. The amount of bank credit used is proxied by the sum of outstanding balances on all loans scaled by the value of total assets. Variable definitions appear in Table 1.

$\mathrm{a}, \mathrm{b}$ and $\mathrm{c}$ indicate statistical significance at the $0.01,0.05$ and 0.10 levels, respectively. 